\title{
Routekaart Zwerfafvalmonitoring Nederlandse rivieren
}

Tim van Emmerik, Paul Vriend

Hydrologie \& Kwantitatief Waterbeheer, Wageningen University
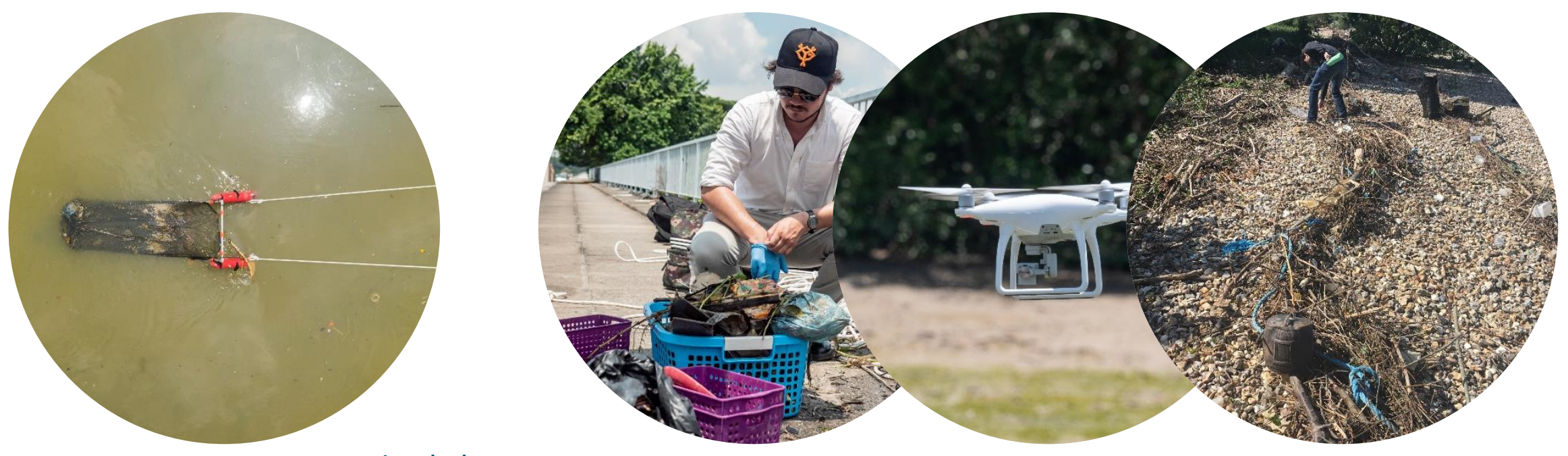


\section{Routekaart Zwerfafvalmonitoring Nederlandse rivieren}

\section{Colofon}

Tim van Emmerik, Assistant Professor Hydrologic Sensing, Hydrologie en Kwantitatief Waterbeheer, Wageningen University \& Research (tim.vanemmerik@wur.nl)

Paul Vriend, Onderzoeker, Hydrologie en Kwantitatief Waterbeheer, Wageningen University \& Research (paul.vriend@wur.nl)

Versie: Januari 2021

Dit rapport is geschreven in opdracht van Rijkswaterstaat.

Dit werk valt onder een Creative Commons Naamsvermelding 4.0 Internationaal-licentie. (C) 2021 T.H.M. van Emmerik en P. Vriend

\section{Referentie:}

van Emmerik, T. \& P. Vriend (2021). Routekaart Zwerfafvalmonitoring Nederlandse rivieren Wageningen University, Report. 57 pp., https:// doi.org/10.18174/537439/

Wageningen University report

ISBN: 978-94-6395-660-4

https://http://doi.org/10.18174/537440/

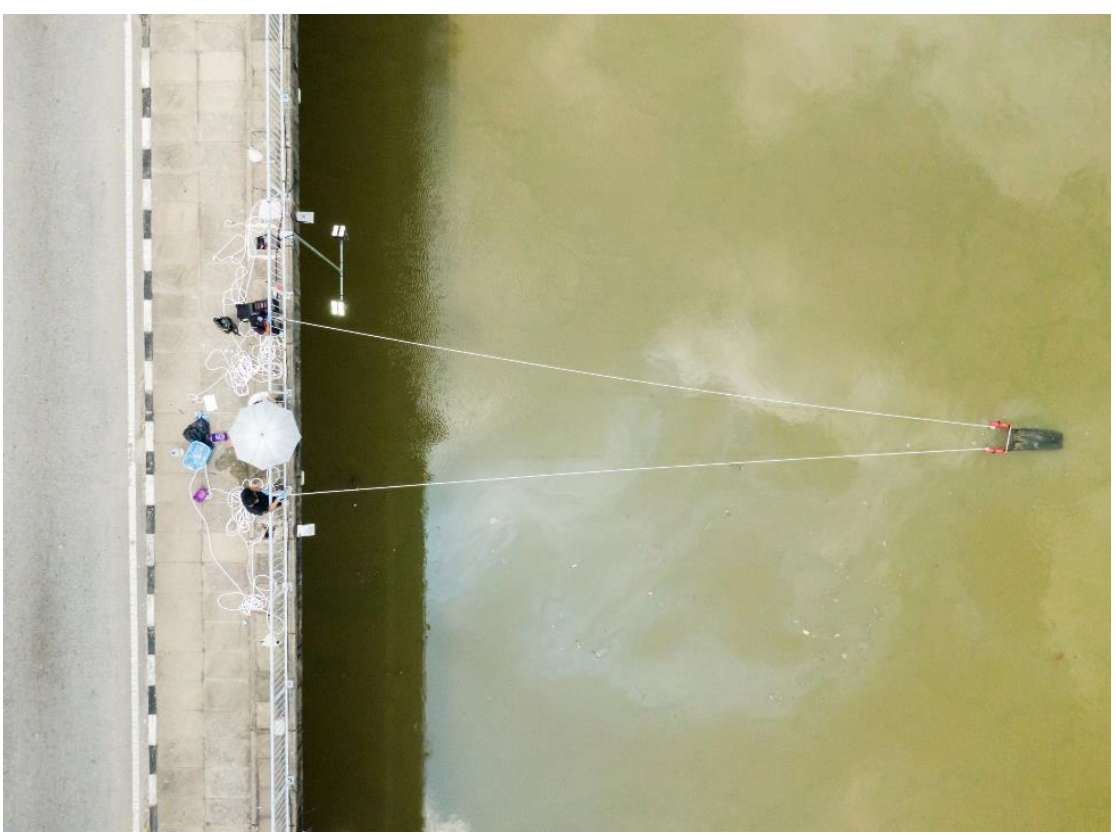




\section{Samenvatting}

Zwerfafval in rivieren heeft een negatieve impact op mens en milieu. Een langetermijn monitoringstrategie zal bijdragen aan (1) beleid, (2) kennisontwikkeling, (3) operationele doelen en (4) evalueren van oplossingen. De Routekaart maakt de samenhang tussen doelen, openstaande vragen en projecten inzichtelijk, en helpt om concrete projecten te formuleren, prioriteren en evalueren. De Routekaart bestaat uit drie niveau's: (1) meettechnieken, (2) nulmetingen, en (3) langetermijnmetingen. Deze fundamentele ontwikkelingen voeden op hun beurt de antwoorden op de grote vragen.

Projectvoorstellen kunnen middels de Routekaart geprioriteerd worden, om een optimale volgorde van uitvoering te bepalen. De Routekaart kan aangepast worden naar aanleiding van nieuwe inzichten vanuit de grote vragen, nieuwe observaties, en technische ontwikkelingen. Door middel van een Dashboard kan direct inzichtelijk worden gemaakt hoe afgeronde projecten beschikbare methoden, kennis en kunde vergroten. De projecten gebundeld in zes clusters: Nieuwe Meettechieken, Meetprotocollen, Nationale Nulmeting, Langetermijnmonitoring, Samenwerking \& Integratie, en Richtlijnen \& Oplossingen. Specifieke projecten kunnen worden toegevoegd of verwijderd. De zes clusters zijn geplaatst op een tijdlijn als suggestie welke projecten prioriteit moeten krijgen op korte, middellange en lange termijn. De Routekaart is geen lineaire oplossing, maar biedt een flexibel raamwerk. Na nieuwe inzichten kan opnieuw de cyclus van doelvragen-routes-projecten-clustering-planning doorlopen worden. Ontwikkeling en optimalisatie van een nationale zwerfafvalmonitoringstrategie is een iteratief proces.
De Routekaart Zwerfafvalmonitoring Nederlandse rivieren

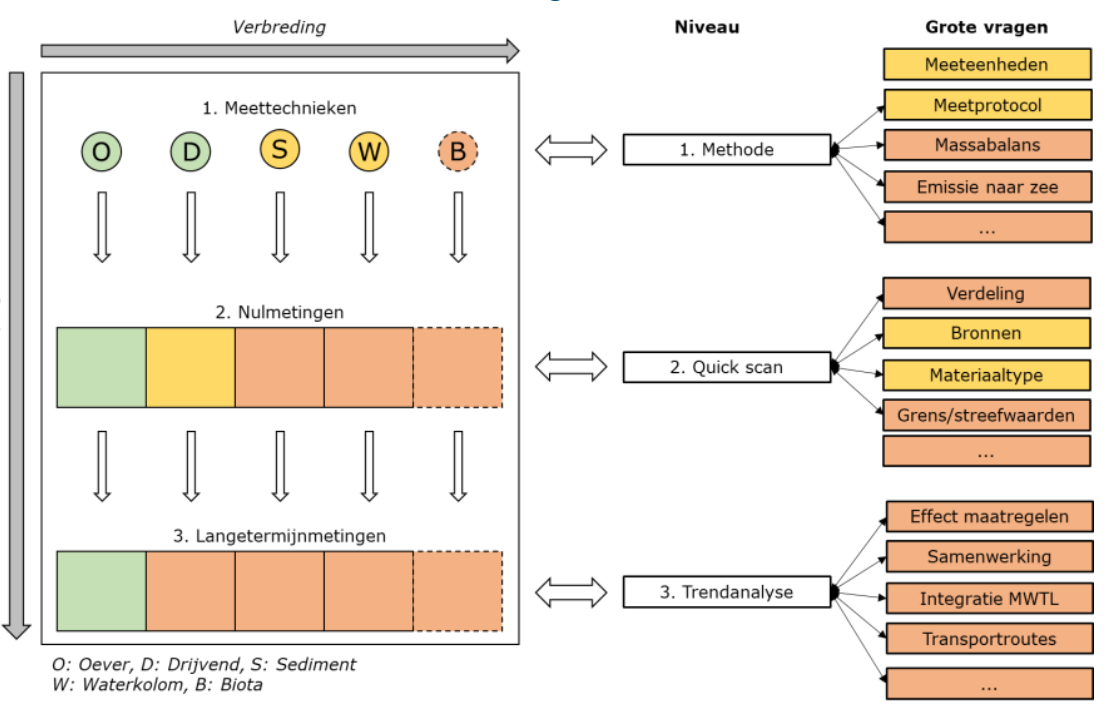

Over de Routekaart

De Routekaart maakt inzichtelijk hoe openstaande vragen en doelen in verband staan met het niveau van monitoring. Dit kan vervolgens gebruikt worden om projecten en acties te formuleren. Zo wordt duidelijk dat voor het kunnen doen van trendanalyses, langetermijnmetingen noodzakelijk zijn. Als deze nog niet beschikbaar zijn, zullen deze eerst gepland moeten worden. Hiervoor zijn echter eerst geschikte meettechnieken en nulmetingen nodig. In de Routekaart zijn verschillende riviercompartimenten opgenomen, omdat de huidige stand van zaken en benodigde stappen hier tussen kunnen verschillen. 


\section{Inhoud}

1. Aanleiding

2. Basisinformatie

3. Ontwikkelingen

4. Richting geven - Doelen voor monitoring

5. Routekaart

6. Stappen naar de toekomst

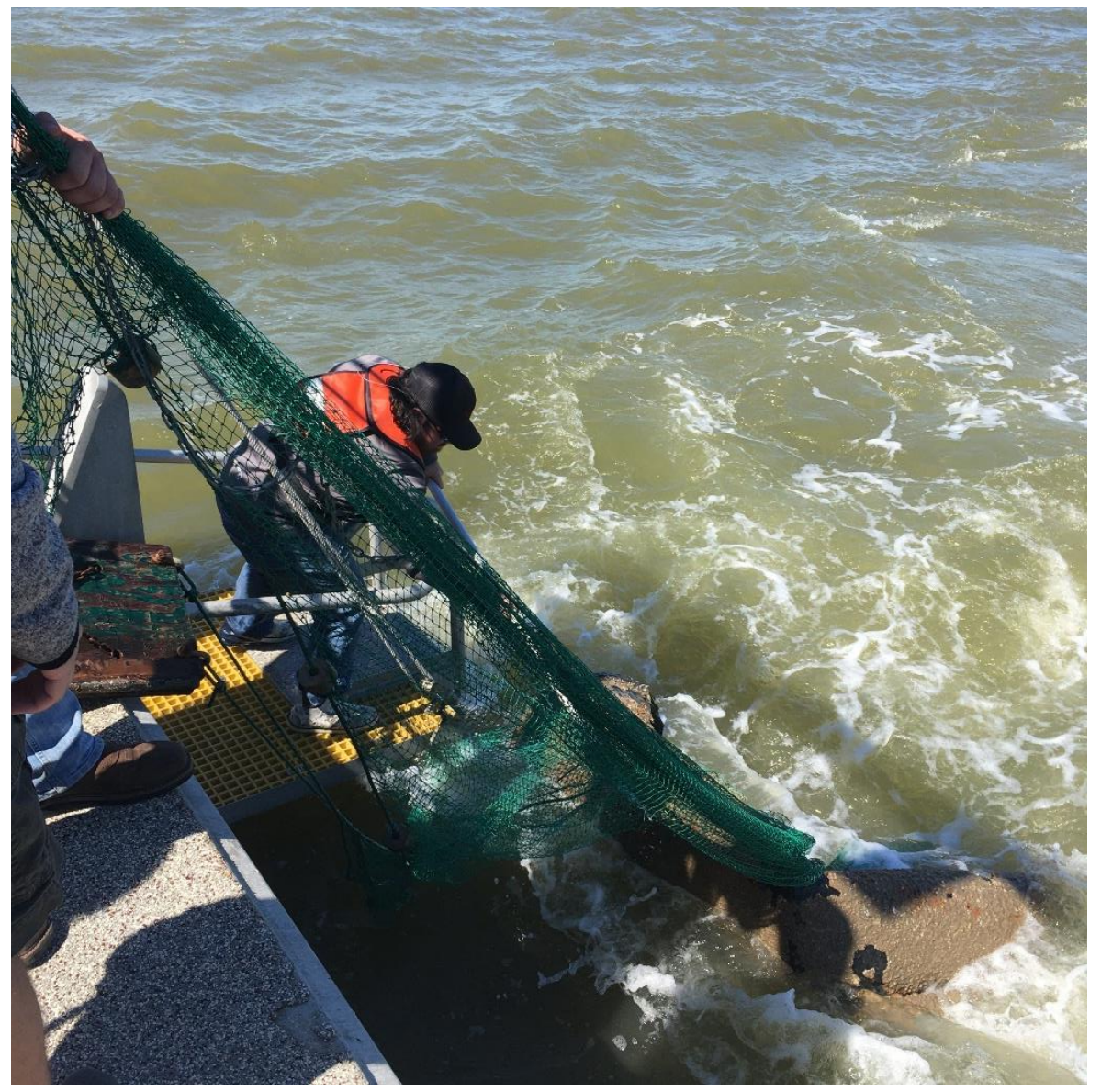




\section{Aanleiding}

Zwerfafval in en rondom rivieren heeft een negatieve impact op mens en milieu. Stukken afval, zoals plastics, worden teruggevonden in de ingewanden van vogels, vissen, en andere aquatische diersoorten. Het zijn vooral de grotere stukken zwerfafval die schade aan scheepvaart en water gerelateerde infrastructuur (verstoppingen in sluizen, pompen) veroorzaken. Voor plastics alleen worden de mondiale economische verliezen op miljarden euro's per jaar geschat.

Voor het optimaliseren van maatregelen ter preventie, mitigatie en verwijdering van zwerfafval in Nederlandse rivieren is het van cruciaal belang om over structurele data, informatie en inzichten te beschikken. Tot op heden is dit echter zeer beperkt, zeker in de Nederlandse riviersystemen.

Met de Routekaart Zwerfafvalmonitoring in Nederlandse rivieren proberen we richting te geven aan de toekomstige ontwikkeling van een geschikte monitoringstrategie.

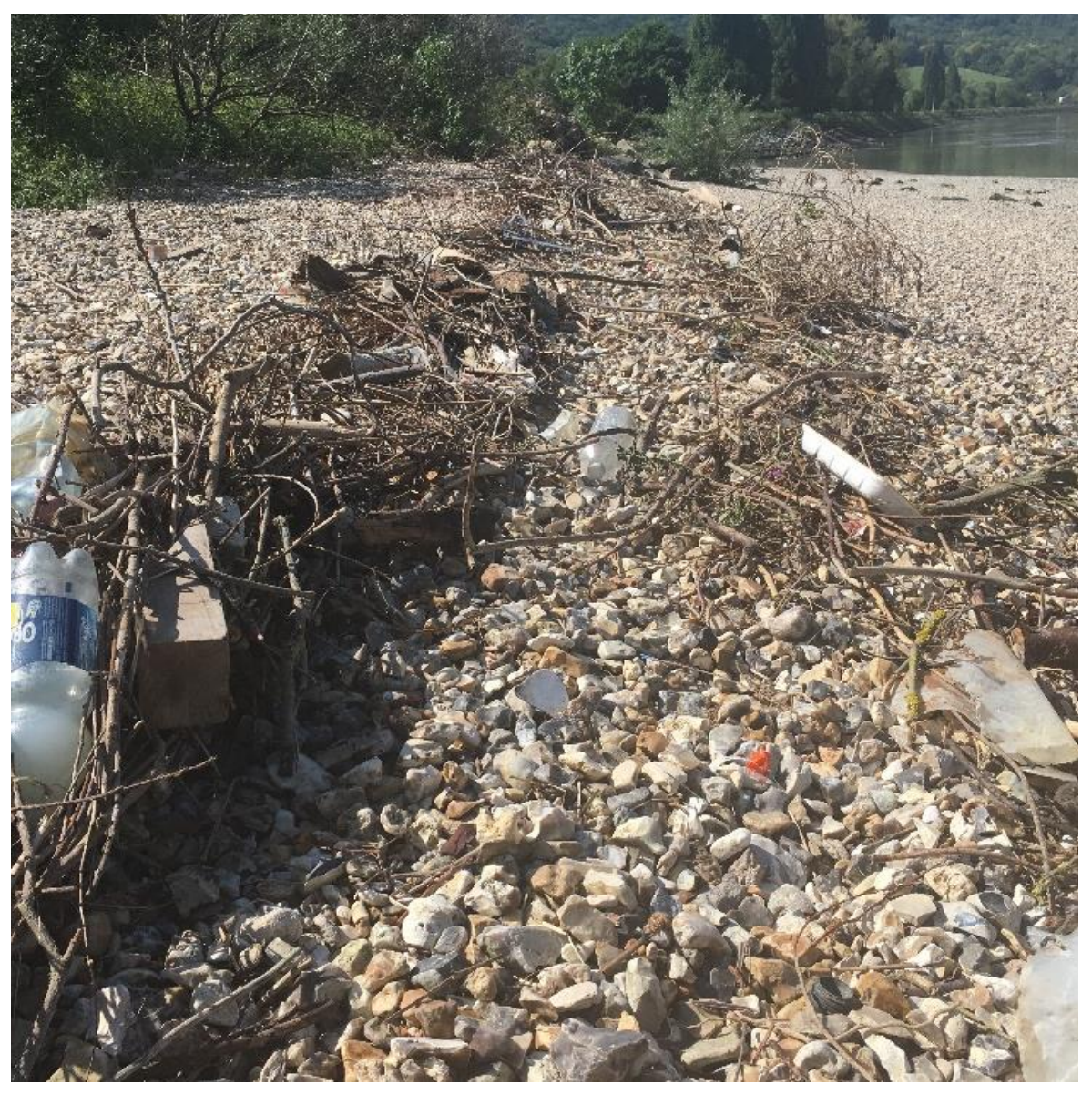




\section{Voorbeelden van negatieve impact}

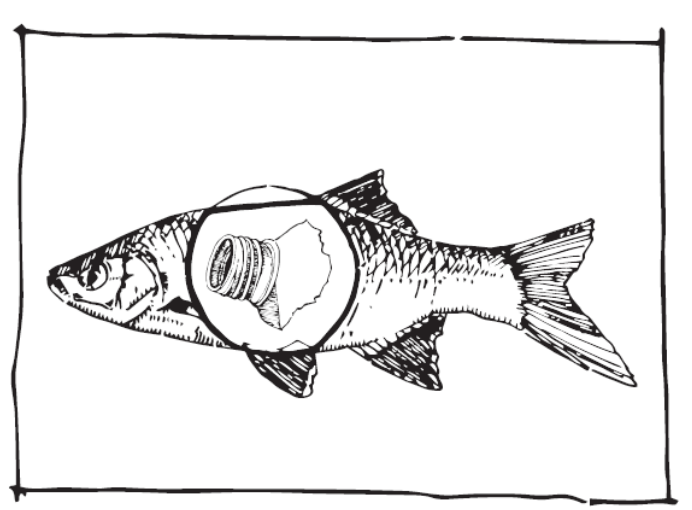

Letsel aan flora en fauna, zoals inname voor vogels, vissen en zoogdieren. Dit kan zelfs dodelijke gevolgen hebben. Ook kan afval leiden tot schade en afsterving van mangrovebossen ${ }^{14}$. Stormvogels die zijn gevonden op Nederlandse stranden hebben bijvoorbeeld gemiddeld 24 stukken plastic in hun maag ${ }^{12}$.

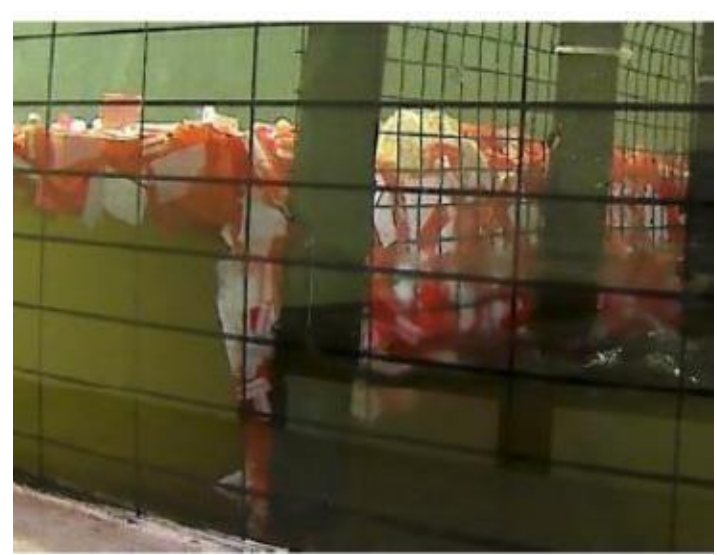

(Plastic) afval veroorzaakt ook economische schade. Plastics kunnen afwatersystemen verstoppen. In vergelijking met organisch afval, resulteert plastic in een snellere en hogere stijging van het waterniveau als gevolg van verstopping. In stedelijke gebieden leidt dit tot extra overstromingsrisico. Zwerfafval is ook in verband gebracht met schade aan schepen, en zelfs scheepsongevallen ${ }^{3,5,8}$.

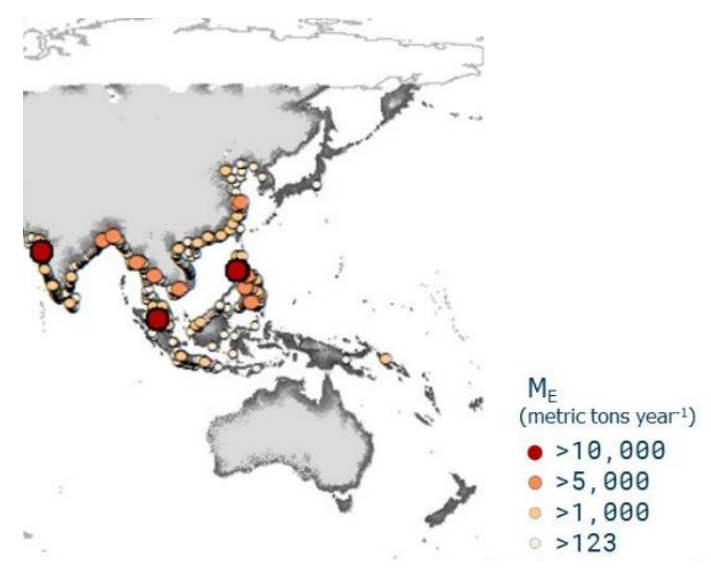

Een deel van het zwerfafval dat in de rivieren terecht komt stroomt naar zee. Er wordt aangenomen dat het grootste deel van de plasticsoep op de oceanen via rivieren wordt getransporteerd. Tot slot zijn macroplastics, een groot deel van het zwerfafval, de grootste bron van microplastics op land, in rivieren en op zee. Het verminderen van zwerfafval zal dus direct leiden tot minder microplastics in het milieu 7,15 . 


\section{Basisinformatie}

We beginnen met achtergrondinformatie en definities van

zwerfafval in rivieren. Zwerfafval komt voor in allerlei soorten en

maten, en we presenteren een kort overzicht van typisch

zwerfafval in rivieren. Daarna laten we zien in welke

riviercompartimenten zwerfafval voorkomt, en hoe we deze

noemen. Tot slot presenteren we een aantal kentallen op basis

van gepubliceerd werk over zwerfafval in Nederlandse en

Europese rivieren.

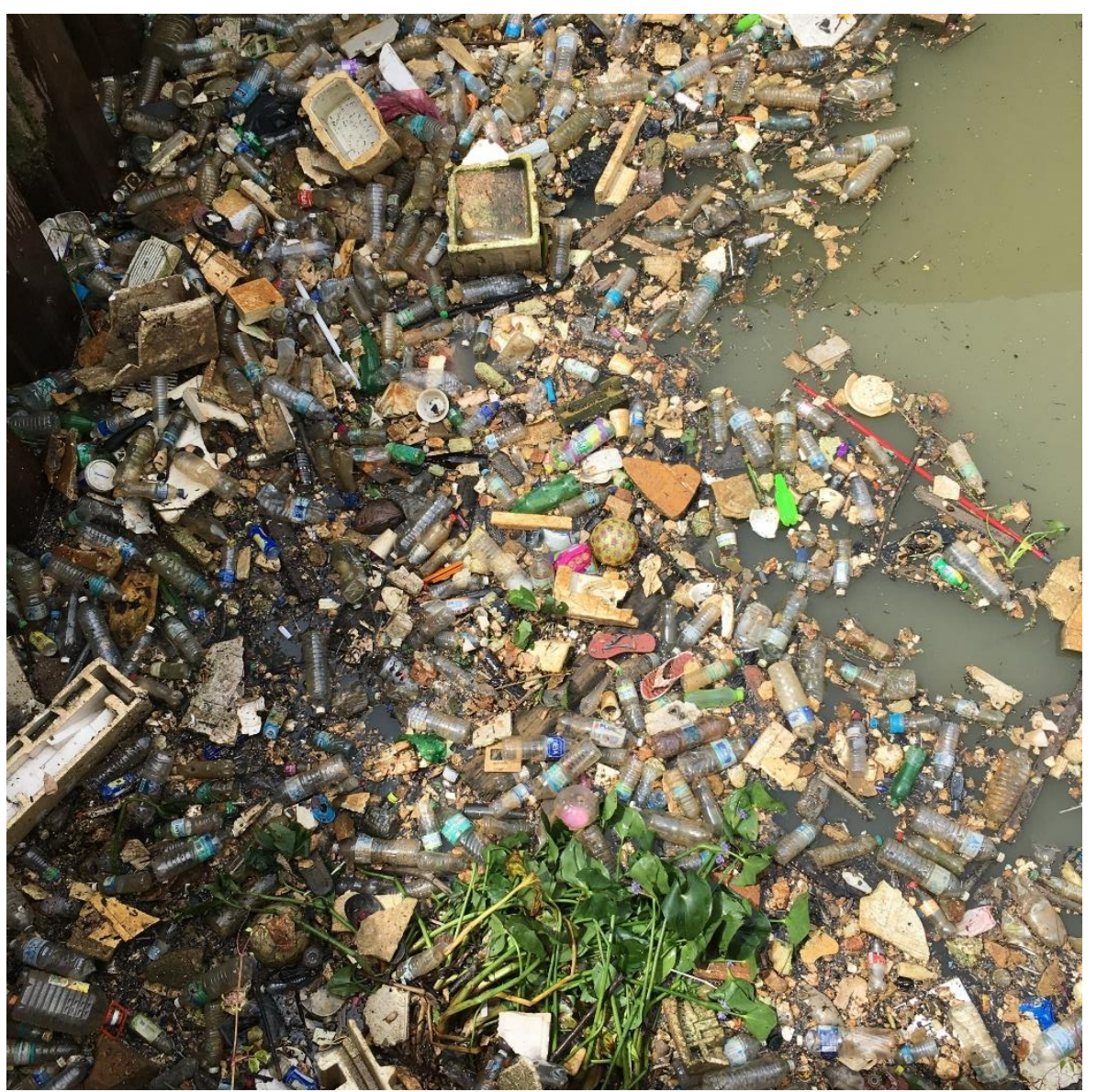




\section{Zwerfafval - Definities}

Zwerfafval kan worden geclassificeerd in materiaaltypes en grootteklassen. Hiervoor wordt gebruikt gemaakt van verschillende classificatiesystemen. Onder zwerfafval verstaan we in dit rapport:

(1) alle anthropogene voorwerpen en fragmenten,

(2) groter dan $0.5 \mathrm{~mm}$.

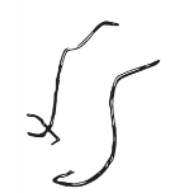

Nano

$<0.1 \mu \mathrm{m}$

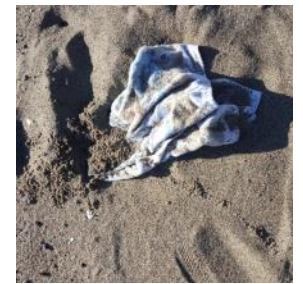

Textiel

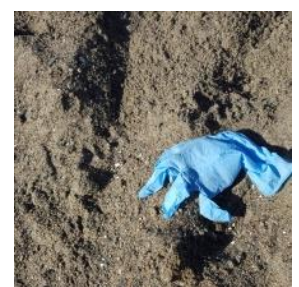

Rubber

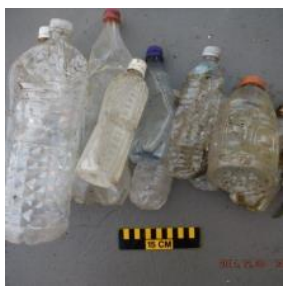

Plastic
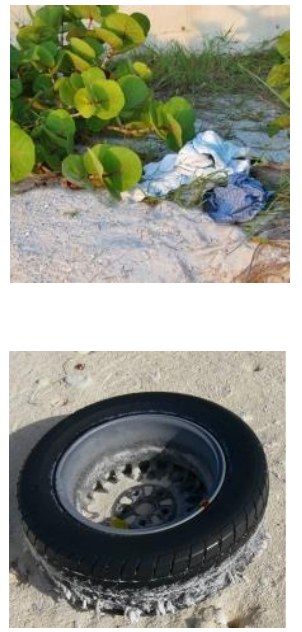

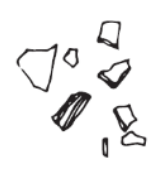

Micro

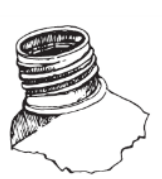

Meso

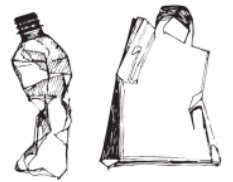

Macro

$>5 \mathrm{~mm}$
$0.5 \mathrm{~mm}-5 \mathrm{~cm}$

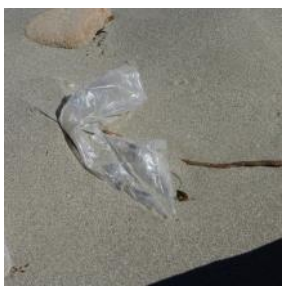

Bron: van Emmerik \& Schwarz (2020)
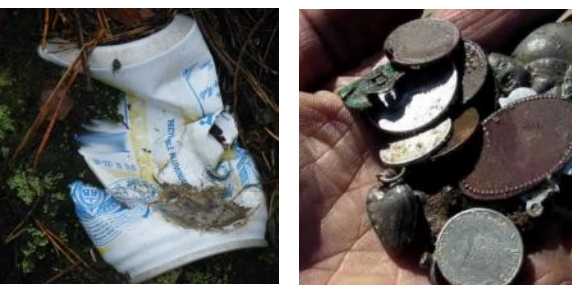

Metaal

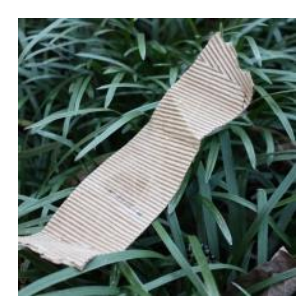

Papier
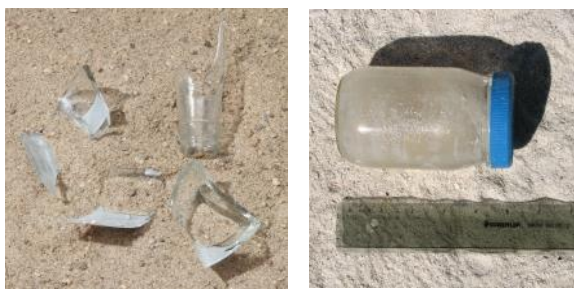

Glas

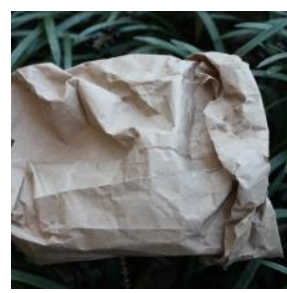

Bron: NOAA Marine Debris Programme 


\section{Zwerfafval - Definities}

Zwerfafval komt voor in alle compartimenten van

rivieren. In de Routekaart onderscheiden we:

(0) - Afval op rivieroever

(D) - Drijvend afval

(S) - Afval in het sediment

(W) - Afval in de waterkolom

(B) - Afval in biota
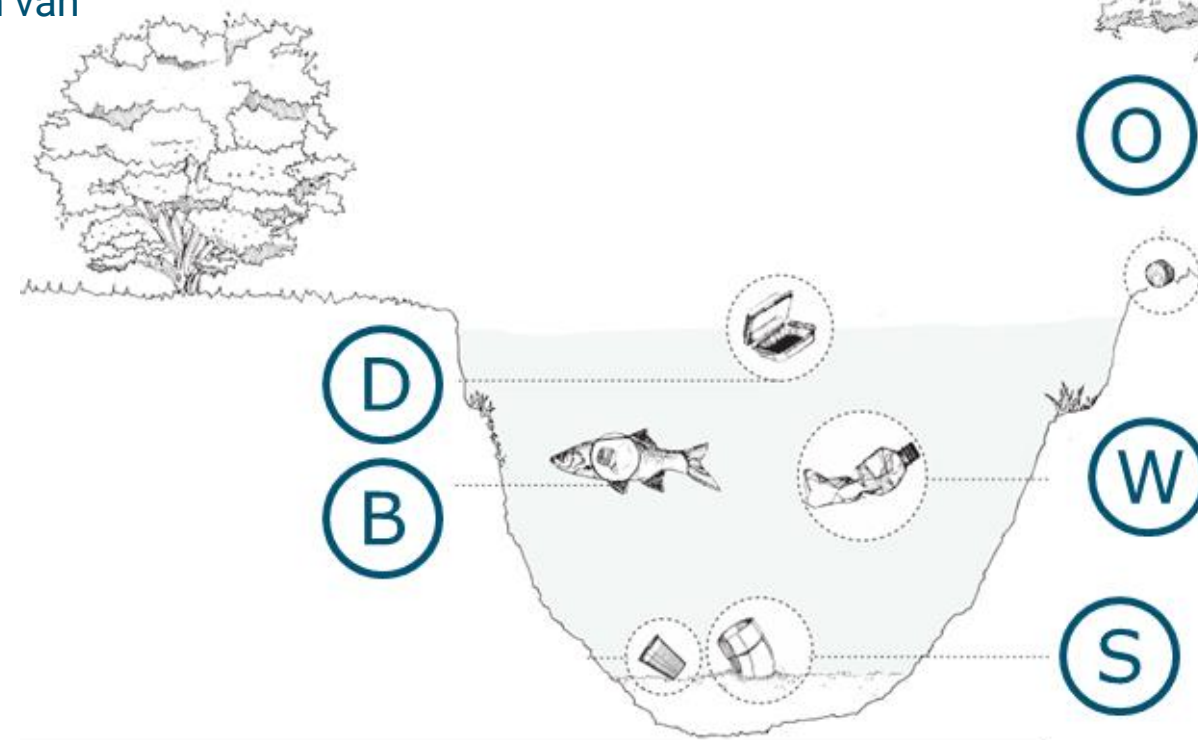


\section{Kentallen zwerfafval in Nederlandse rivieren}

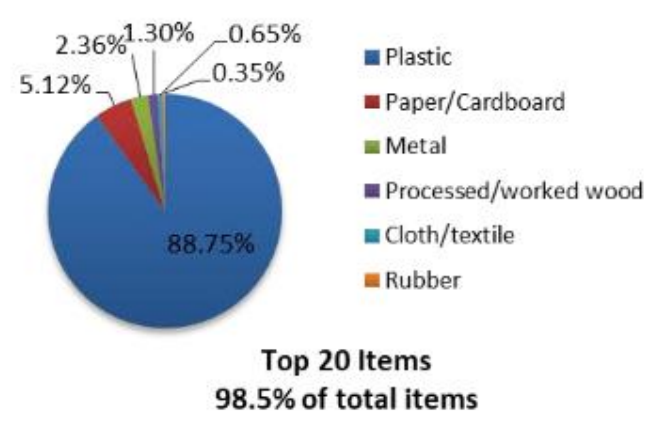

Plastics is het meest voorkomende materiaal (89\%) van drijvend zwerfafval in rivieren in de Noordwestelijke Atlantische regio ${ }^{4}$.

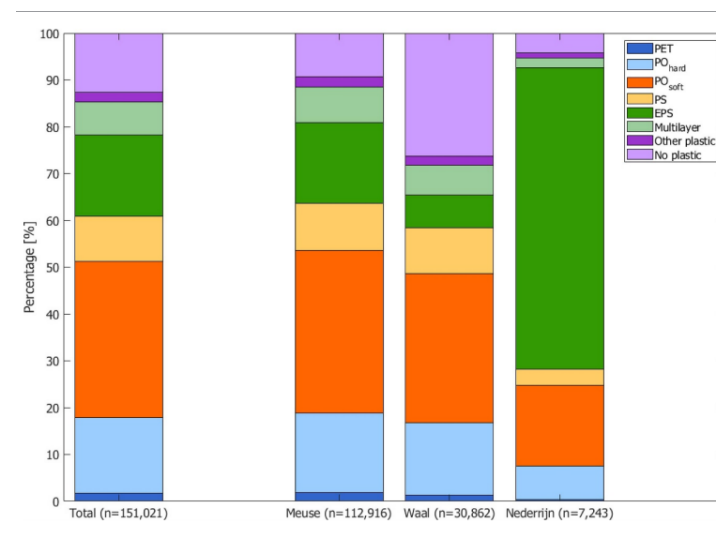

Van het gevonden zwerfafval op de oevers van de Waal, Maas en Nederrijn is $88 \%$ plastic ${ }^{11}$.

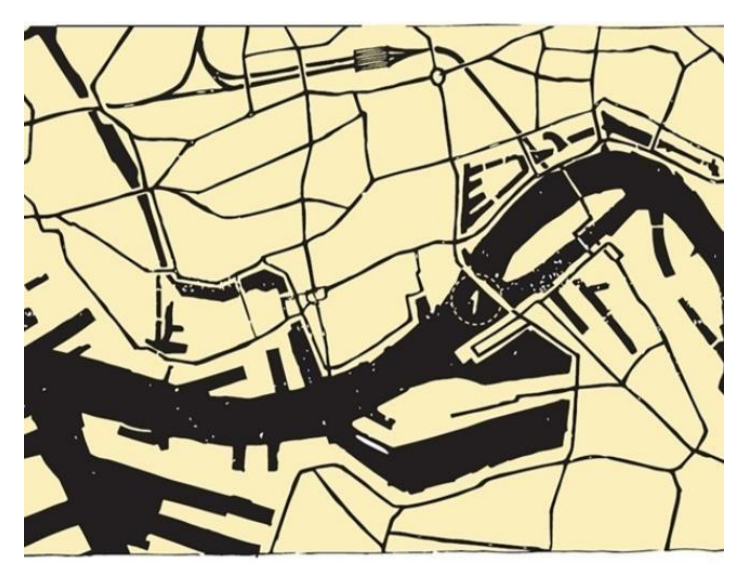

Schattingen van emissie van (plastic) zwerfafval van de Rijn naar de Noordzee variëren behoorlijk:

(1) $1.3-9.7 \mathrm{~kg} / \mathrm{dag}-0.5-3.5 \mathrm{ton} / \mathrm{jaar}^{16}$

(2) $16-160 \mathrm{~kg} / \mathrm{dag}-5.8-58$ ton/jaar ${ }^{11}$

(3) $1,900-6,300 \mathrm{~kg} / \mathrm{dag}-694-2,300$ ton/jaar ${ }^{7}$

De laagste en hoogste schatting verschillen meer dan 10 drie ordegroottes. 


\section{Recente ontwikkelingen}

In de afgelopen jaren zijn er veel ontwikkelingen geweest op het gebied van zwerfafvalmonitoring in watersystemen. In rivieren, kustgebieden, steden, en riviermonden. Veel projecten zijn gebaseerd op citizen science, zoals Schone Rivieren,

Scouts4Science en Plastic Spotter. Andere projecten monitoren middels afvangsystemen (Clear Rivers, Noria), of via ad-hoc monitoringsprojecten (WUR, The Ocean Cleanup).

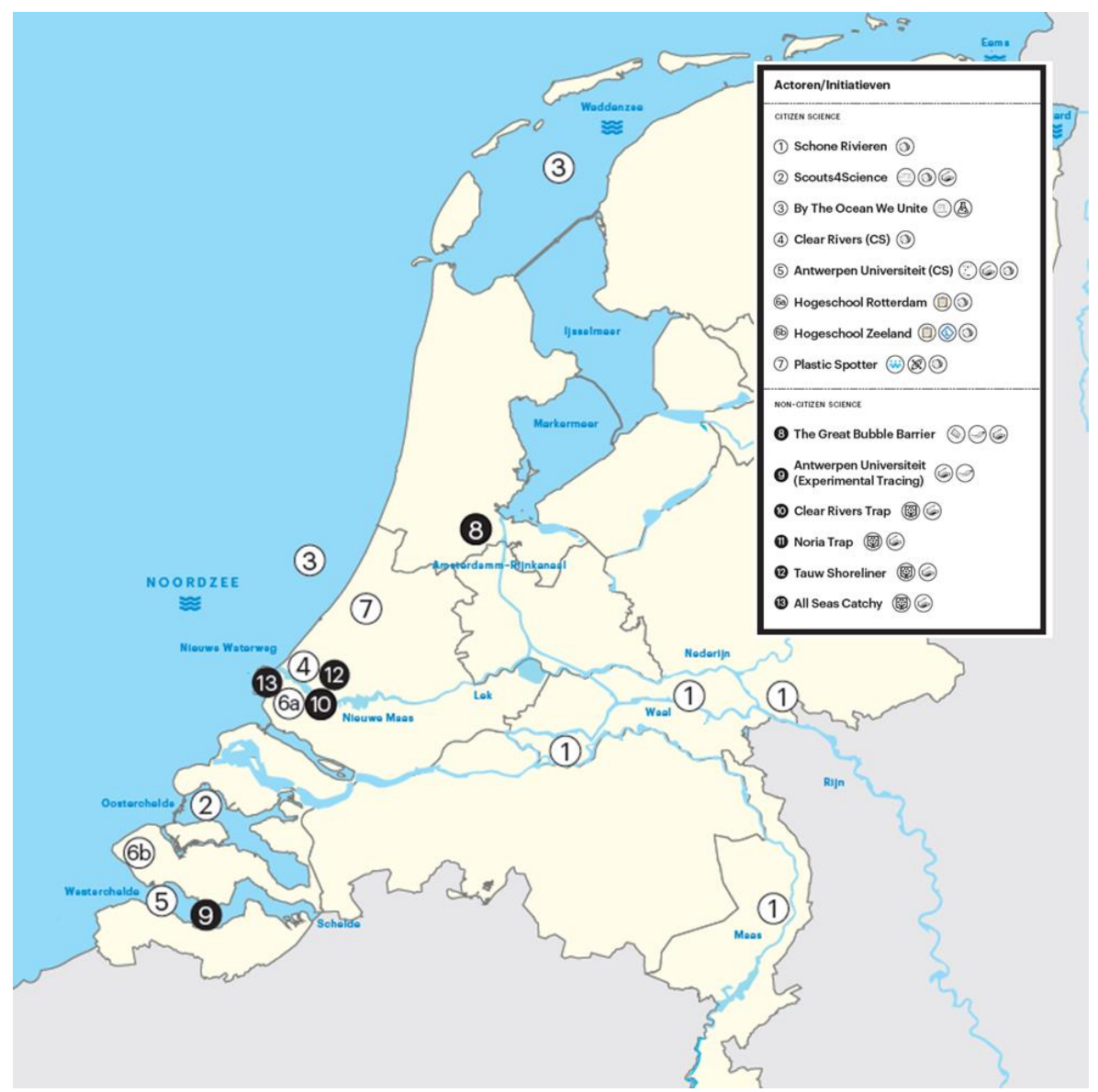




\section{Ontwikkelingen binnenland}

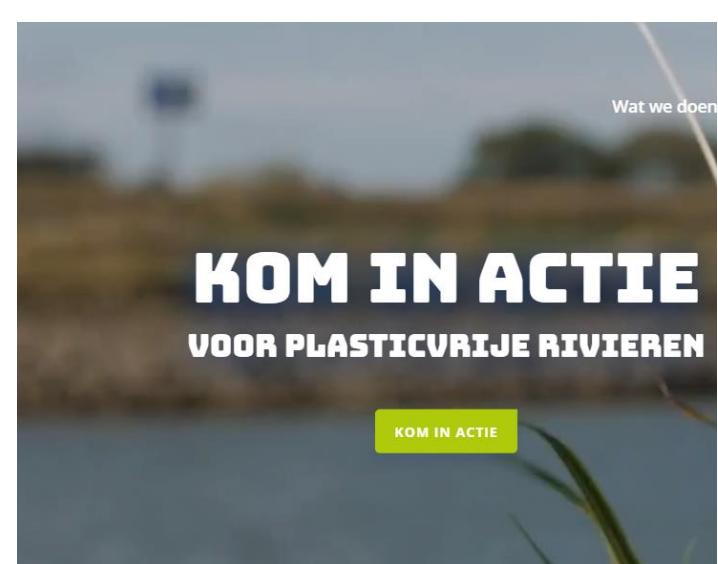

Monitoring Schone Rivieren. Rivieroevers van de Rijn en Maas worden sinds 2017 tweemaal jaars gemeten door vrijwilligers van Stichting de Noordzee (SDN). Het project en haar resultaten dient als inspiratie voor toekomstige monitoring van andere compartimenten.

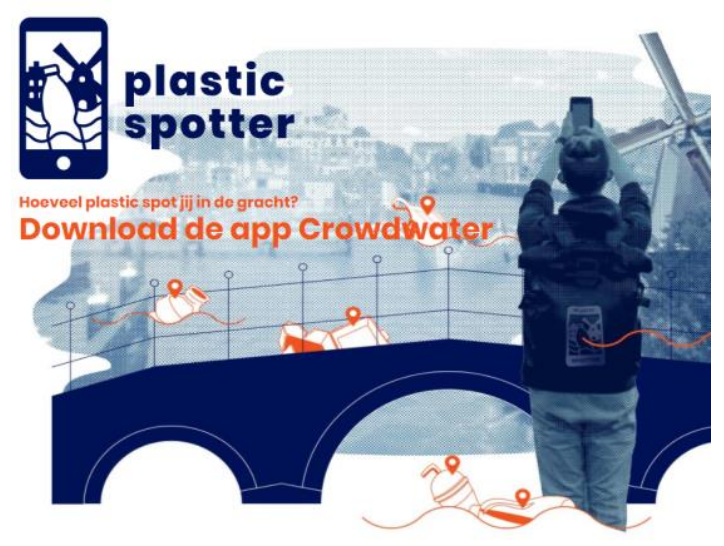

Een groeiend aantal citizen science-projecten focust op het verzamelen van data over zwerfafval in Nederlandse watersystem, van steden (Plastic Spotter), riviermonden (lear Rivers) en hele rivieren (Schone Rivieren).

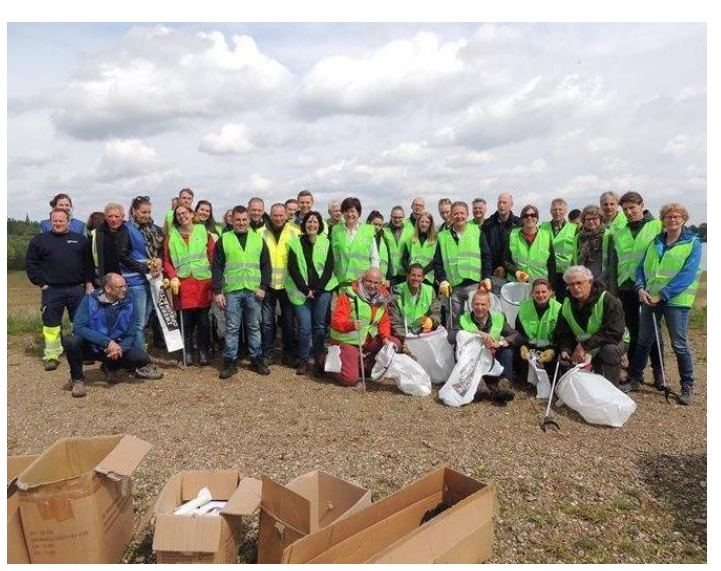

Het nieuwe LIVES-project focust op het verminderen van zwerfafval in de Maas met $50 \%$, middels grensoverschrijdende samenwerking tussen verscheidene stakeholders (universiteiten, overheden). 


\section{Ontwikkelingen buitenland}

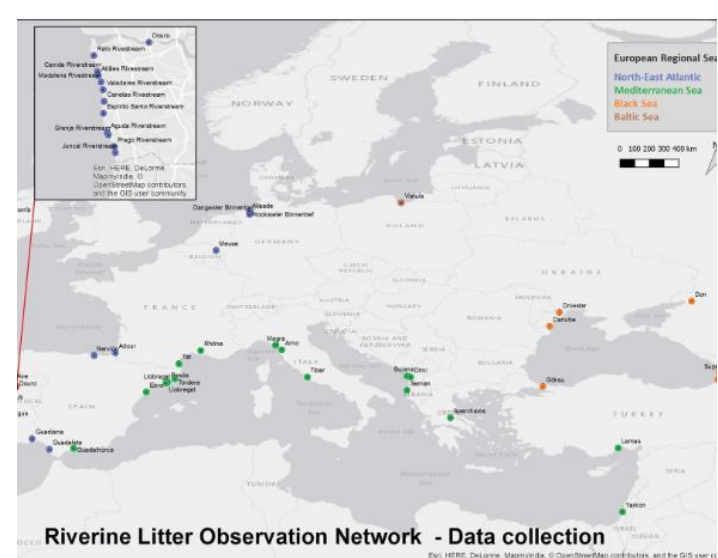

Het Europese RIMMEL-project ${ }^{4}$ heeft tussen 2016 en 2017 meer dan 50 rivieren gemonitord verspreid over heel Europa. Metingen waren gefocust op drijvend zwerfafval.

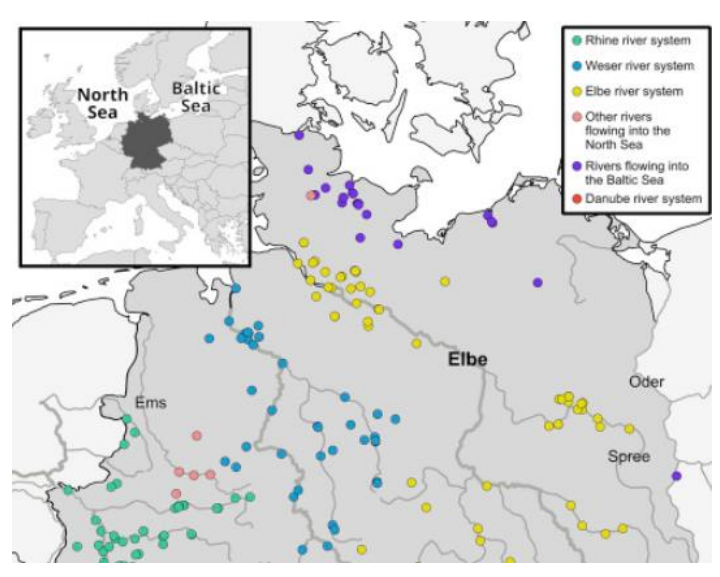

In de grote Duitse rivieren is tussen 2016 en 2017 een nationale nulmeting van zwerfafval op rivieroevers uitgevoerd. De metingen zijn gedaan door schoolkinderen als onderdeel van een onderwijsmodule op basisscholen ${ }^{6}$.

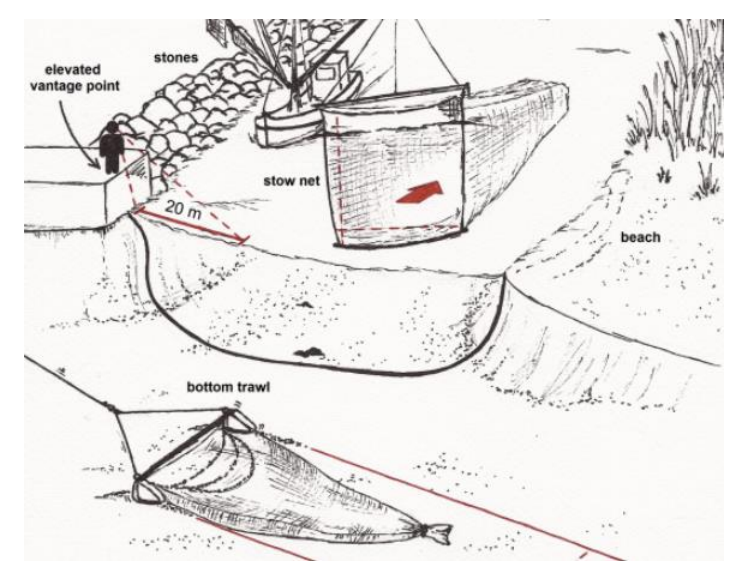

Voor de Eems, Weser en Elbe (Duitsland) is een eerste methode ontwikkeld om de massabalans op te stellen. In de drie rivieren is zwerfafval op oevers, drijvend, in de waterkolom en in het sediment gemeten ${ }^{10}$. 


\section{Richting de toekomst}

Voor het vormgeven van de Routekaart hebben we in September een rondvraag uitgestuurd naar RWSexperts. Hier hebben we input gekregen over de redenen om zwerfafval te monitoren, welke indicatoren daarvoor kunnen worden gebruikt, en welke doelen gesteld kunnen worden op korte (1-3 jaar), middellange (3-5 jaar) en lange termijn ( 5 jaar). Dit hebben we als input gebruikt voor het opstellen van de Routekaart en voor het definiëren en prioriteren van specifieke projecten.

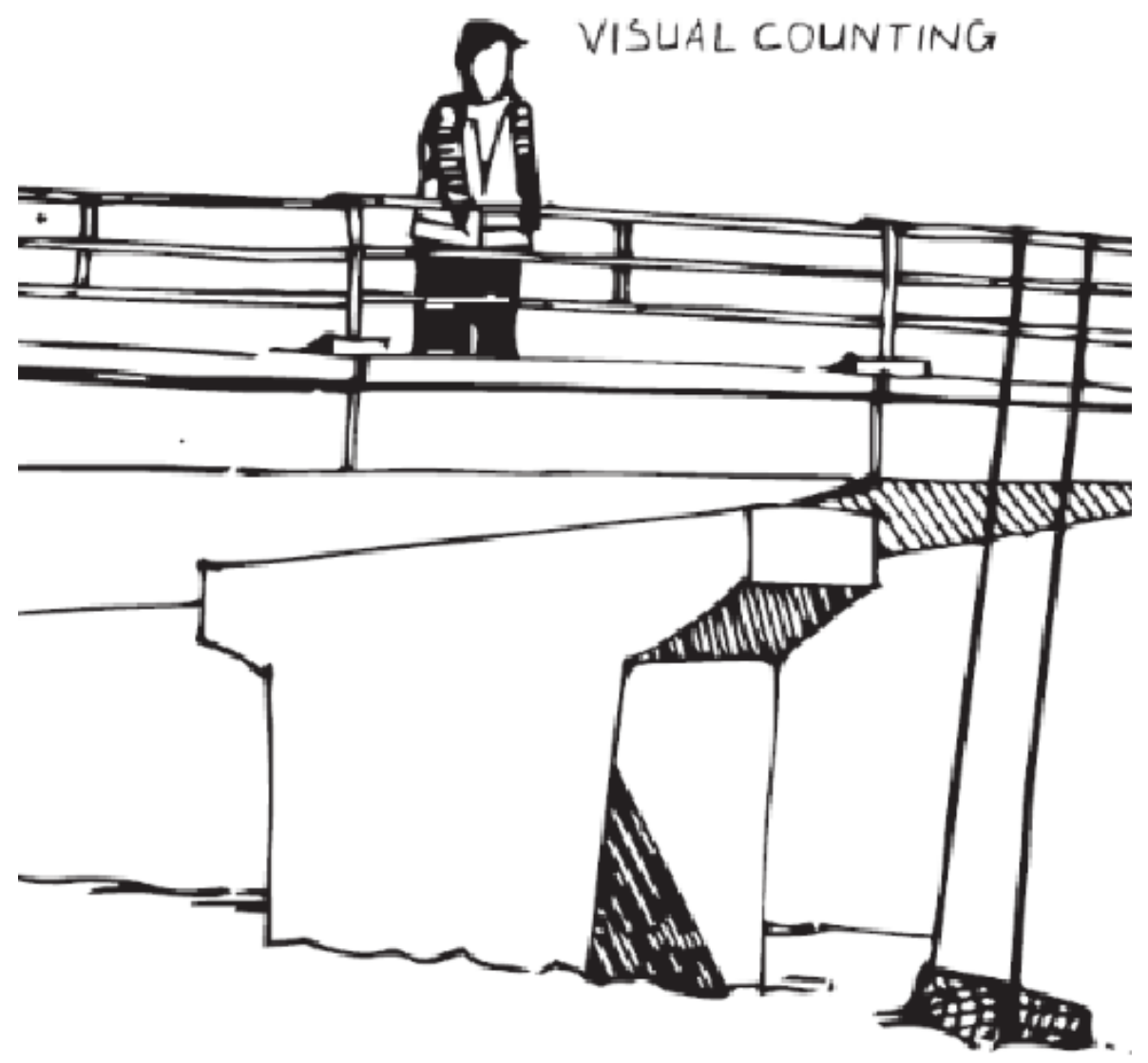




\section{Wie heeft input gegeven?}

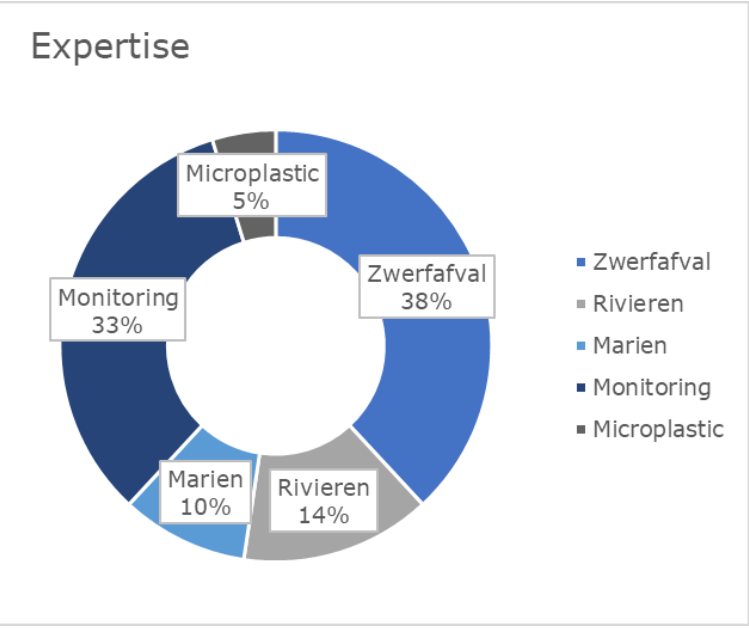

Er is veel inbreng gekomen van experts

$(n=16)$ met expertise zwerfafval en

monitoring.

\section{Werkzaamheden}

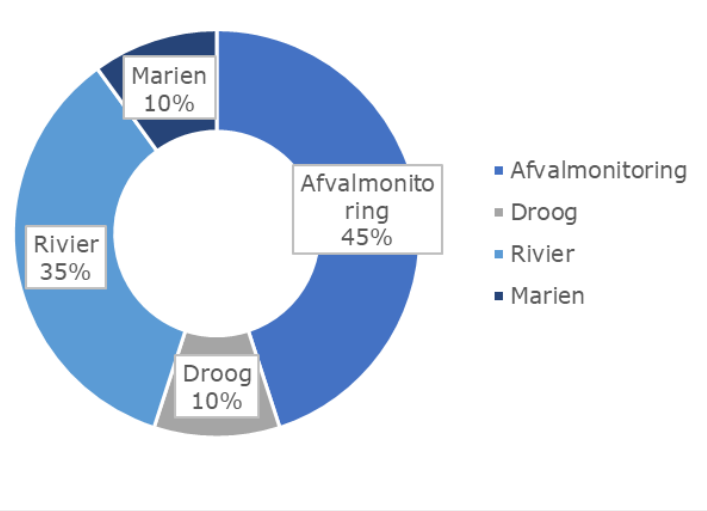

De meeste input is gekomen vanuit de

domeinen afvalmonitoring en rivieren.

\section{Afdeling}

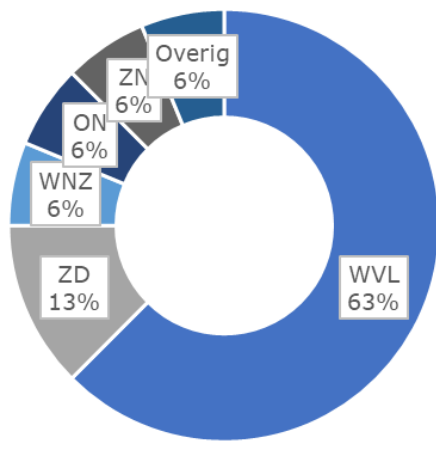

- WVL

$\because Z D$

- WNZ

- ON

$-\mathrm{ZN}$

- Overig

De meeste experts zijn werkzaam bij WVL, maar bijna een-derde heeft input geleverd vanuit andere afdelingen.

\section{Afkortingen:}

WVL - Water, Verkeer en Leefomgeving; ZD - Zee en delta; WNZ - West-Nederland-Zuid; ON - OostNederland; ZN - Zuid-Nederland 


\section{Wat hebben we geleerd?}

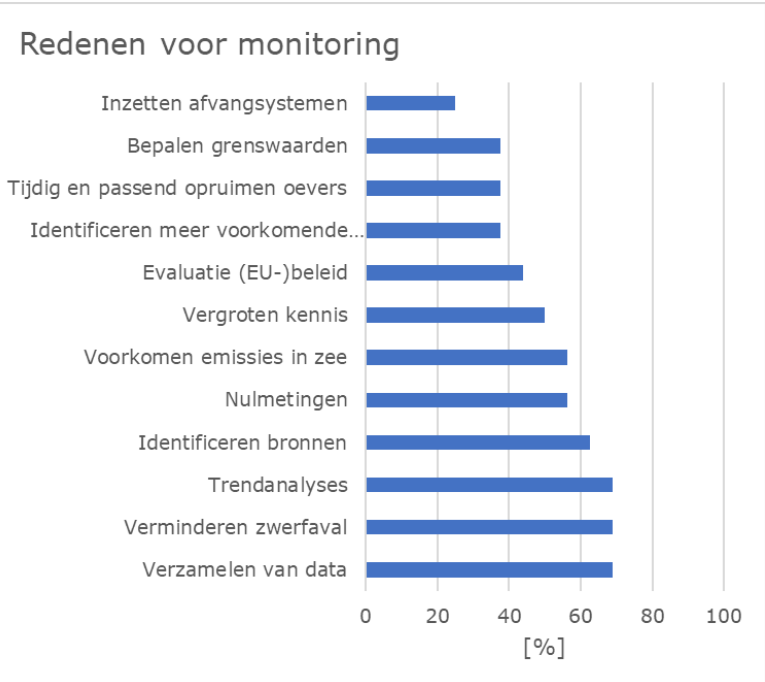

De meest genoemde redenen zijn het verzamelen van data, verminderen zwerfafval en uitvoeren van trendanalyses. Het inzetten van afvangsystemen is een van de minder genoemde redenen.

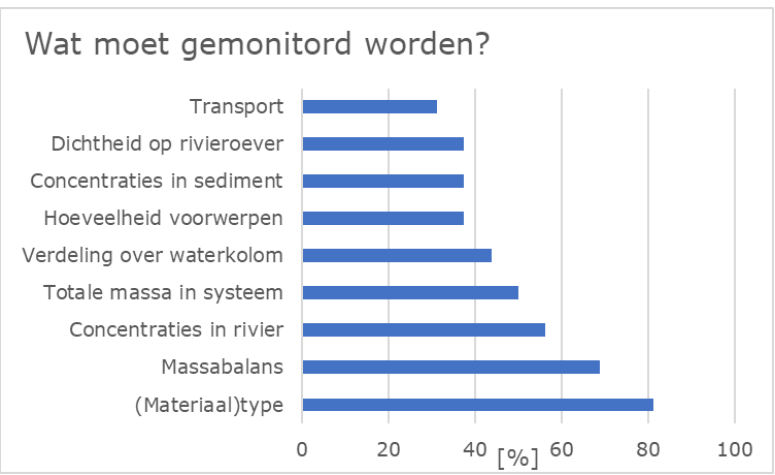

Volgens het expertpanel moeten vooral variabelen gemeten worden gerelateerd aan (materiaal)type en de massabalans. De specifieke variabelen (concentraties, dichtheid) zijn minder genoemd.
Huidig kennisniveau

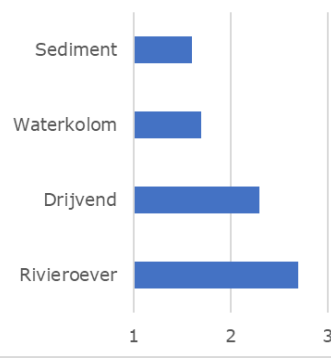

Het huidige kennisniveau wordt het hoogst ingeschat voor rivieroevers en drijvend zwerfafval. Sediment en waterkolom worden het laagst ingeschat. Dit is in lijn met de literatuur en de projecten die al worden uitgevoerd in en buiten Nederland. 


\section{Vier redenen om te monitoren}

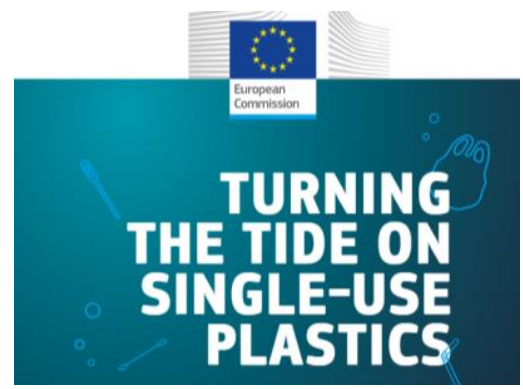

Beleid

- Richtlijnen Europese Unie en Nederlandse overheid, zoals Kaderrichtlijn Water (KRW) en Kaderrichtlijn Marien (KRM).

- Beleid naar aanleiding van de Kamerbrief gezamelijke aanpak plastic zwerfafval.

- Afstemming buurregio's.

- Aanpak specifieke voorwerpen
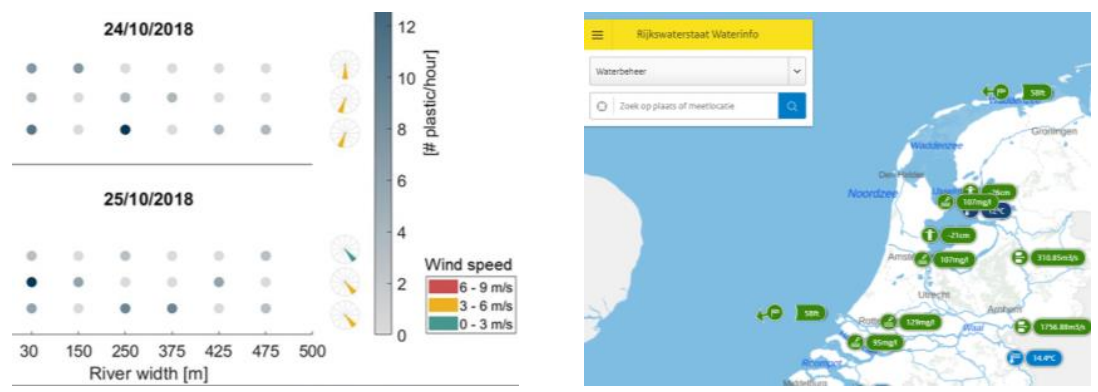

\section{Kennisontwikkeling}

- Beter begrijpen bronnen, routes, materiaaltypes.

- Verdeling zwerfafval over riviercompartimenten.

- Response van zwerfafval na hoogwatergolf of storm.

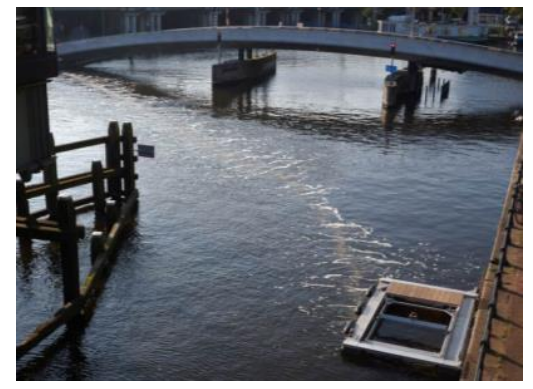

\section{Operationeel}

- Onderdeel van RWS-taak.

- Integratie met het programma Monitoring Waterstaatkundige Toestand des Lands (MWTL).

\section{Oplossing}

- Ontwerpen maatregelen.

- Optimaliseren bestaande infrastructuur.

- Evalueren van alle soort maatregelen, van beleid tot verwijdering 


\section{Tussendoelen van zwerfafvalmonitoring}

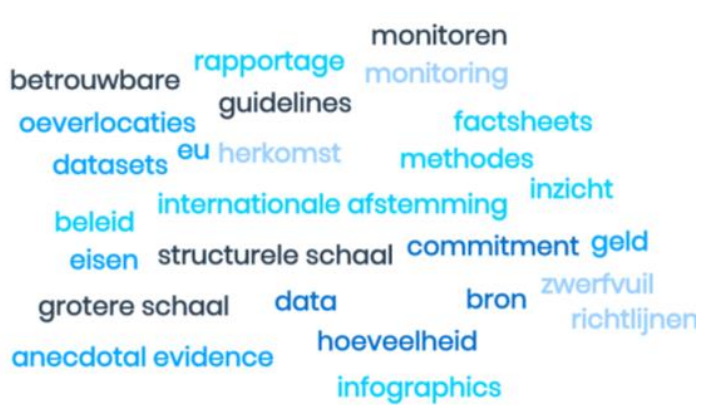

Korte termijn (1-3 jaar)

- Methodes

- Richtlijnen

- Data

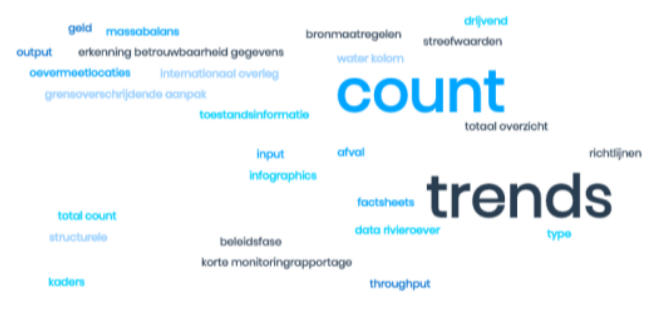

Middellange termijn (3-5 jaar)

- Aantallen zwerfafval

- Trends

- Betrouwbare gegevens
Lange termijn ( $>5$ jaar)

- Bronaanpak

- Meetbaar effect

- Landelijke en structurele monitoring 


\section{Routekaart}

De Routekaart bestaat uit drie onderdelen. Ten eerste een lijst met grote vragen die moeten worden beantwoord voor de verschillende doeleinden (beleid, kennis, operationeel, oplossingen). Ten tweede hebben we structuur aangebracht in de vragen, door drie niveaus van vragen te definiëren. Dit bij elkaar vormt de Routekaart, die aangeeft voor welke vragen, wat voor type projecten nodig zijn. De huidige stand van zaken kan volgens een simpele kleurcode worden aangegeven in het Dashboard (groen $=$ voltooid, oranje $=$ gestart, rood $=$ niet gestart). Tot slot presenteren we een lijst met concrete projecten die invulling geven aan de doelen die op korte, middellange en lange termijn gesteld zijn. Projecten worden vervolgens ondergebracht in een van de zes projectclusters (hoofdstuk 6), die als geheel gepland en uitgevoerd kunnen worden.

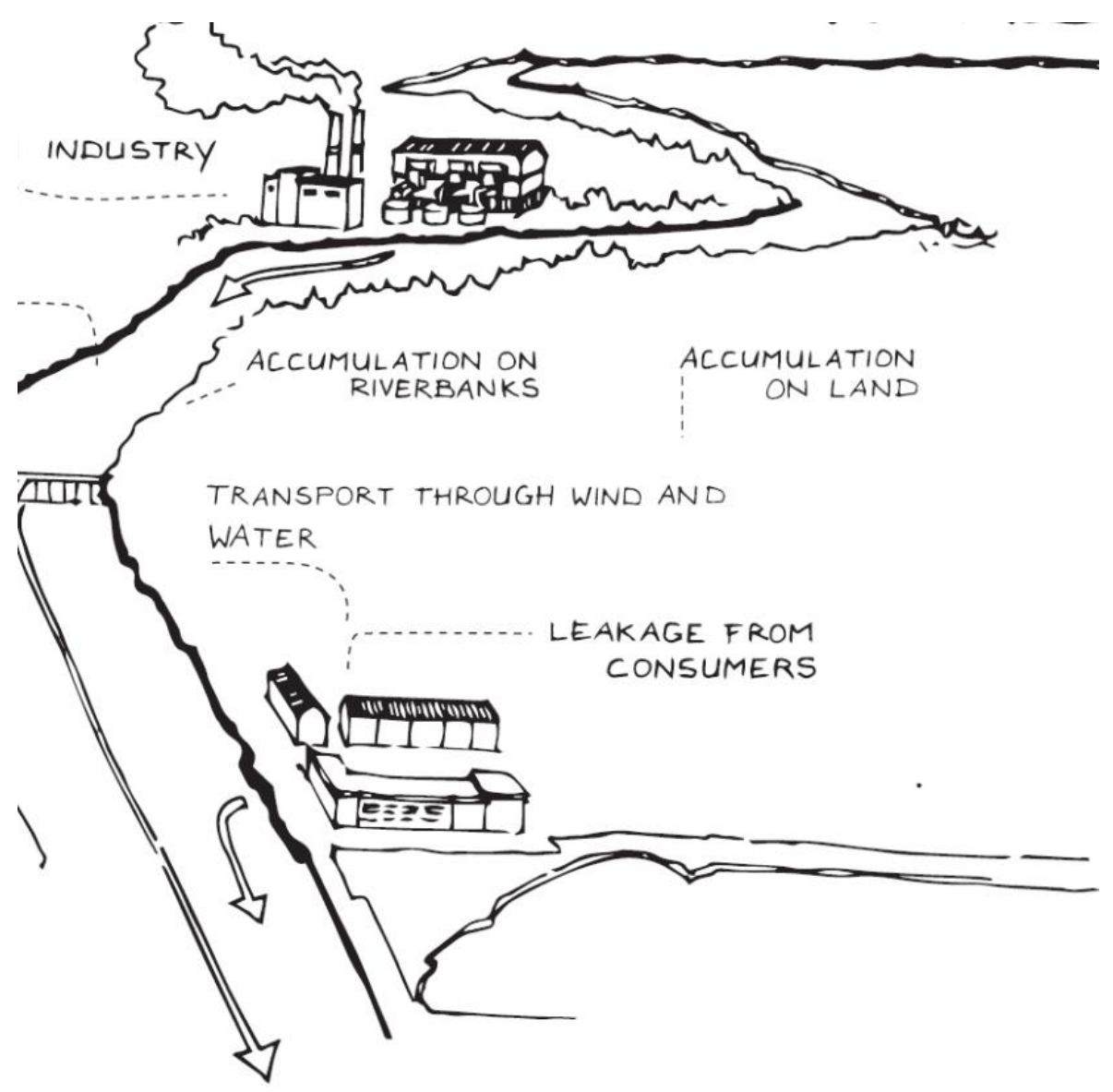




\section{De grote vragen}

Hoe kan zwerfafval in elk riviercompartiment

Hoe bepalen we zwerfafval hotspots in tijd en ruimte? 


\section{De grote vragen}
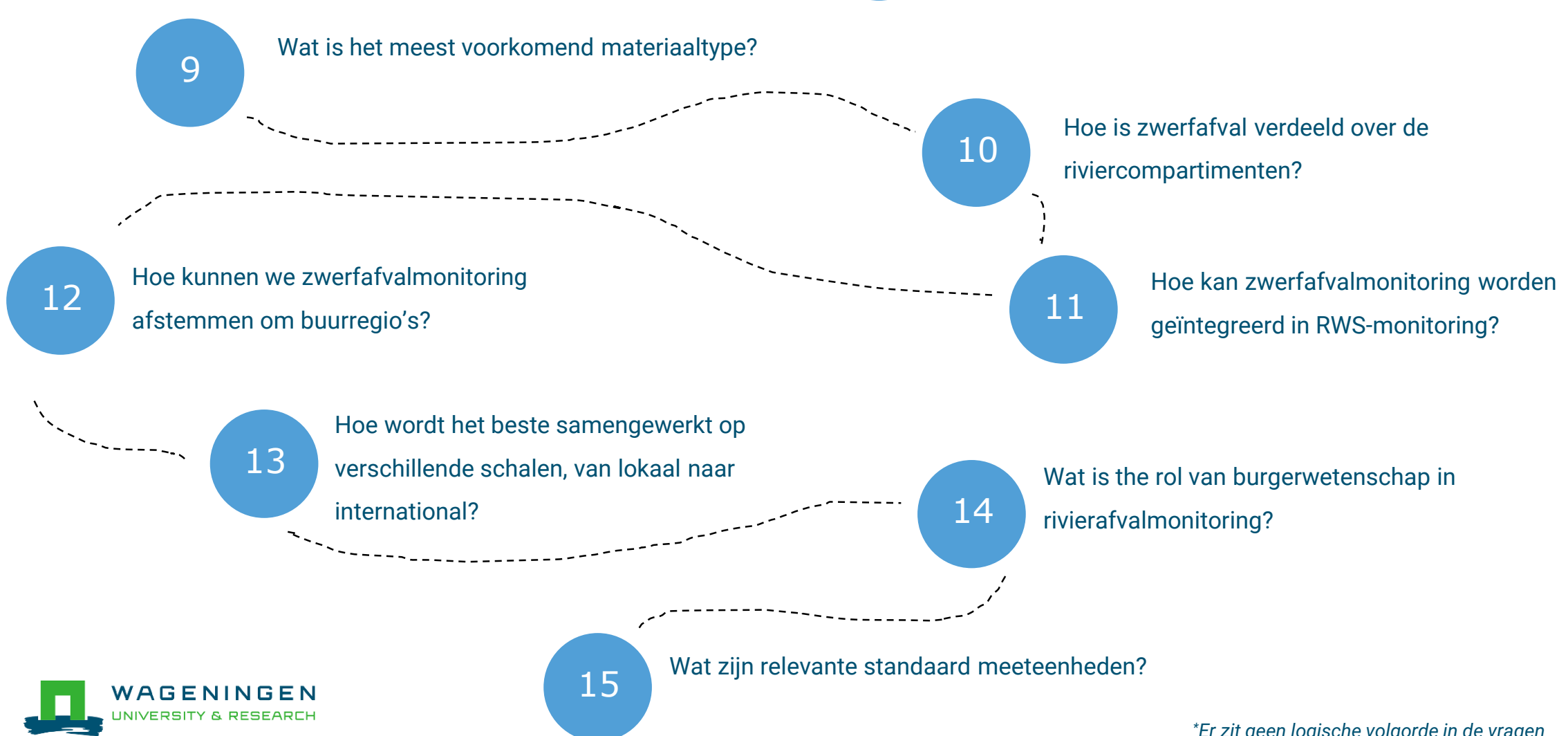

Hoe wordt het beste samengewerkt op

verschillende schalen, van lokaal naar international?

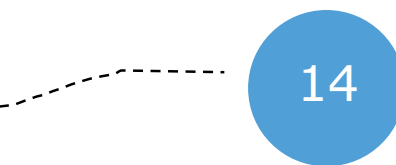

Wat is the rol van burgerwetenschap in rivierafvalmonitoring? 


\section{Structuur in de vragen}

Alle vragen zijn gerelateerd aan data. En data kan alleen verzameld worden als er geschikte meettechnieken zijn. De routekaart bestaat daarom uit drie niveaus:

(1) Meettechniek: Het ontwikkelen of toepassen van nieuwe technieken, meetprotocollen, en methodologieën.

(2) Nulmetingen: Eerste observaties om inzicht te krijgen in de ordegrootte, samenstelling, hotspots en bronnen.

(3) Langetermijnmonitoring: Structurele dataverzameling die nodig is voor trendanalyses, integratie met buurregio's en andere monitoringsprogramma's, en het meten van effecten.
Niveau 1: Meettechniek

\section{Niveau 2: Nulmetingen}

Niveau 3: Langetermijnmonitoring 


\section{Routekaart}

\section{Zwerfafvalmonitoring}

In de Routekaart zijn twee

uitbreidingsmogelijkheden: verdieping en

verbreding. Verdieping is het bereiken van een

nieuw niveau, bijvoorbeeld van nulmetingen

naar langetermijnmonitoring. Verbreding is het uitbreiden van de strategie met nieuwe

riviercompartimenten. Bijvoorbeeld door de oevermetingen $(0)$ uit te breiden met metingen van drijvend (D) afval en afval in sediment (S).
0

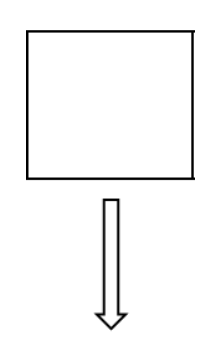

Niveau 1: Meettechniek

Verbreding

Niveau 2: Nulmetingen

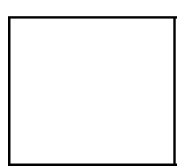

Niveau 3: Langetermijnmonitoring
(0)

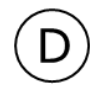

(s)
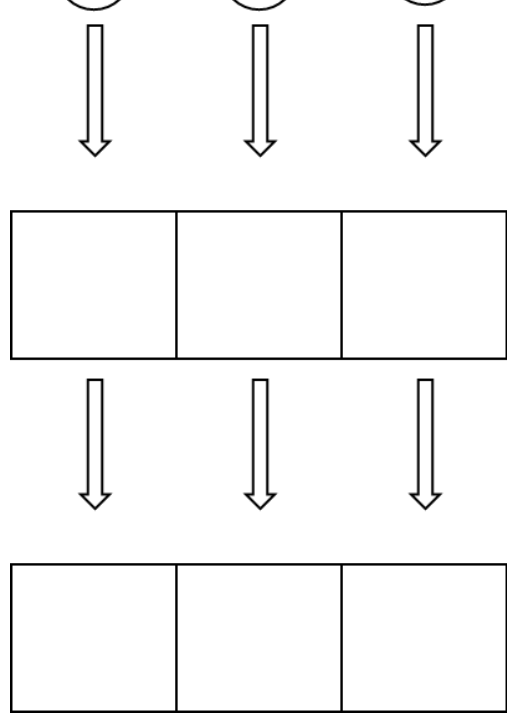

O: Oever, D: Drijvend, S: Sediment 


\section{Routekaart}

\section{Zwerfafvalmonitoring}

Tot slot koppelt de Routekaart elk niveau aan de vragen die op dat niveau beantwoord kunnen worden. Op niveau 1 gaat dit over vragen over hoe afval gemeten moet worden of hoe transport bepaald moet worden. Op niveau 2 zijn dit vragen over verdeling tussen compartimenten en bronnen. Op niveau 3 zijn dit vragen met betrekking tot trendanalyses en het effect van maatregelen.
Verbreding

1. Meettechnieken

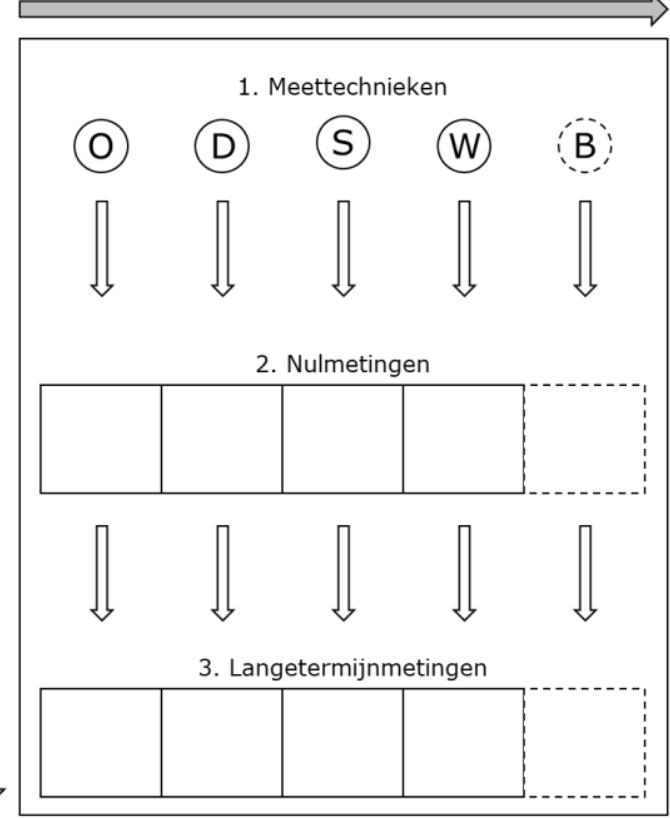

O: Oever, D: Drijvend, S: Sediment W: Waterkolom, B: Biota

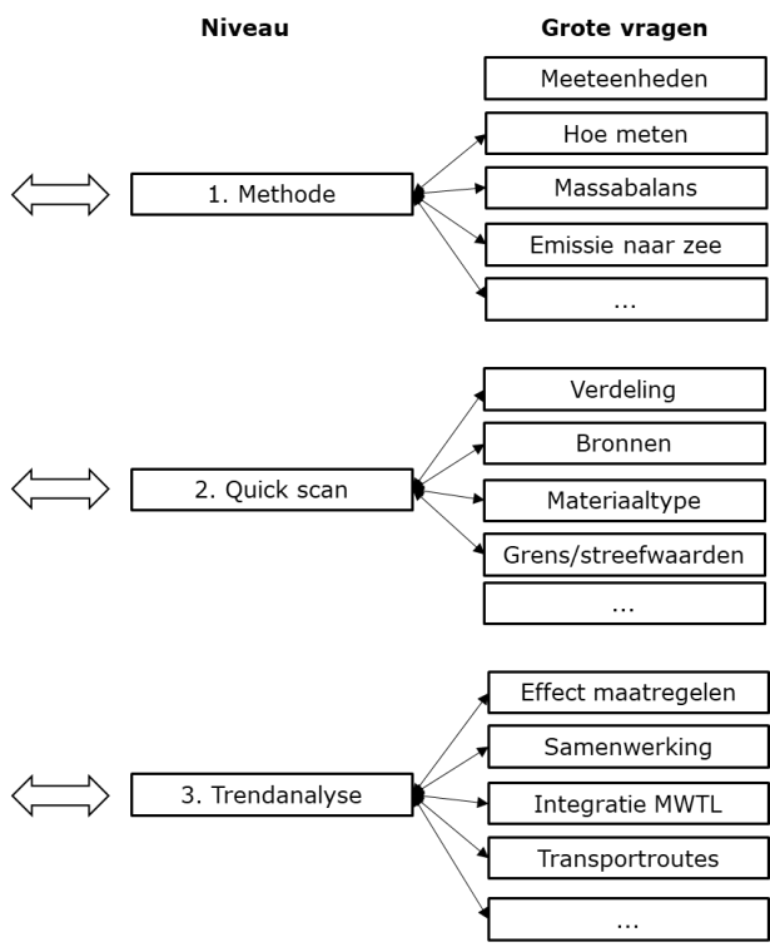




\section{Routekaart}

\section{Zwerfafvalmonitoring}

De Routekaart kan gebruikt worden om inzichtelijk te maken wat de weg is naar het bereiken van een doel. In het voorbeeld is het doel "Effect maatregelen aantonen" voor drijvend afval. Deze vraag kan alleen met data op niveau 3 beantwoord worden; langetermijnmetingen. Op dit moment is er nog geen methode of data van nulmetingen beschikbaar. Deze stappen zullen dus eerst gezet moeten worden, en vormen samen de gehele route van start naar doel.

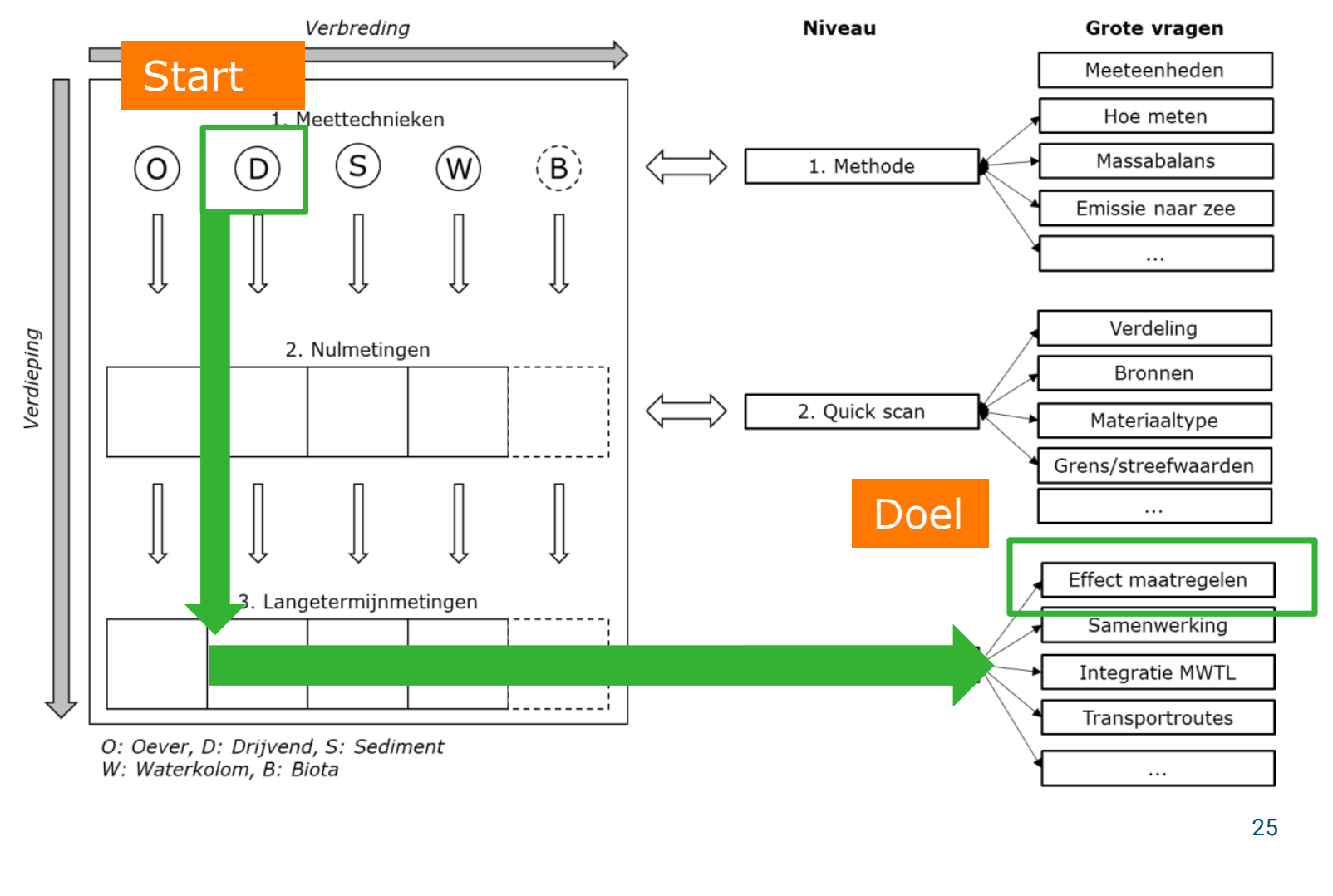




\section{Routekaart als dashboard}

Tot slot kan de Routekaart ook gebruikt worden als Dashboard om weer te geven wat de huidige stand van zaken is omtrent monitoring. In het voorbeeld is een vrije interpretatie weergegeven van de huidige staat van zwerfafvalmonitoring in Nederland. Het is direct duidelijk dat vragen op niveau 2 en 3 nog niet beantwoord zijn of kunnen worden, vooral omdat er nog weinig meettechnieken en -protocollen beschikbaar zijn voor Nederlandse rivieren. Het Dashboard laat zo zien in welke volgorde projecten gepland moeten worden om de beoogde vragen te beantwoorden.

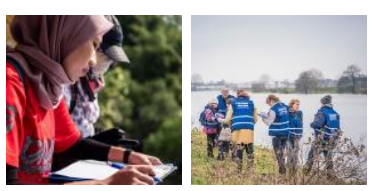

Telmetingen drijvend en oever

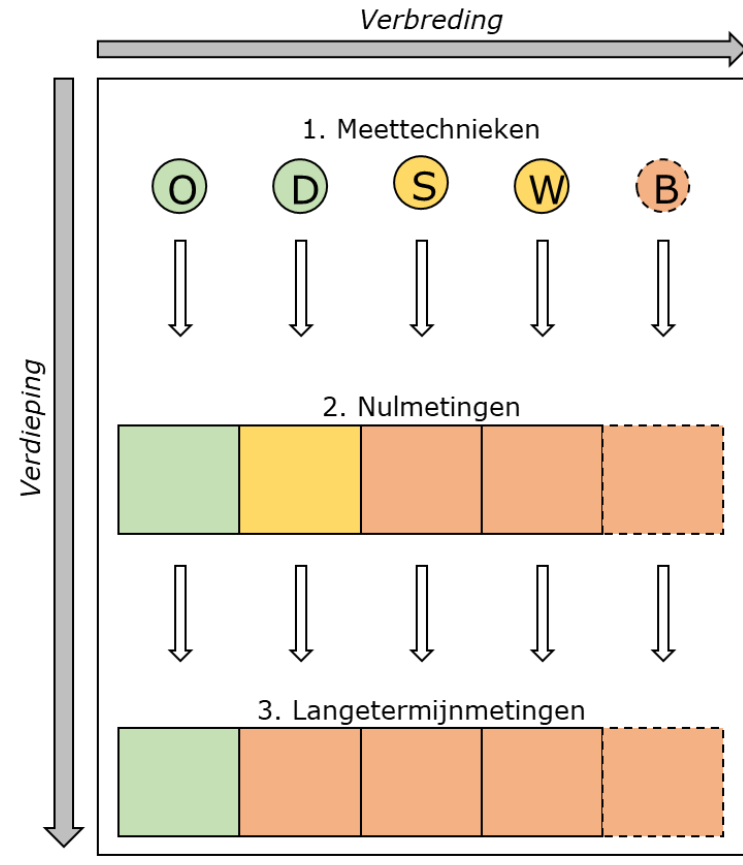

O: Oever, D: Drijvend, S: Sediment

W: Waterkolom, B: Biota
Getest in Nederland

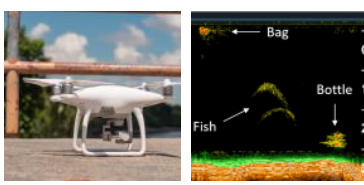

Drones en sonar

Niveau

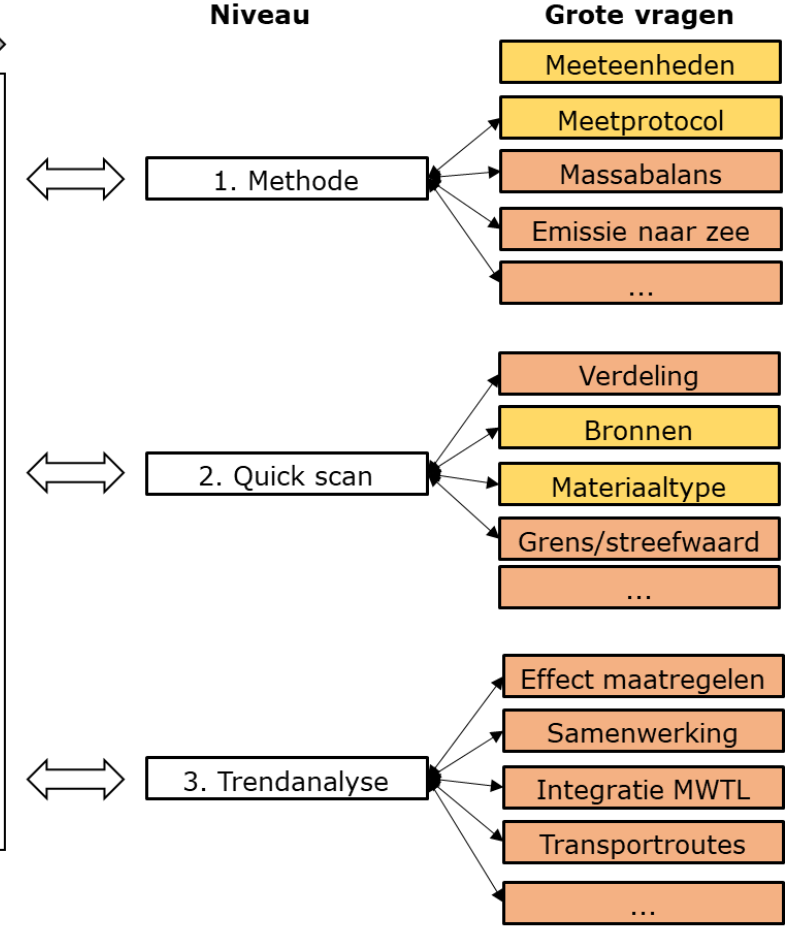




\section{De eerste stappen}

Op basis van Routekaart en Dashboard kan worden bepaald wat voor projecten relevant zijn. Prioritering kan vervolgens worden aangebracht door elk voorstel te scoren op (1) urgentie, (2) belangrijkheid, (3) tijd/kosten en (4) verwachte impact.

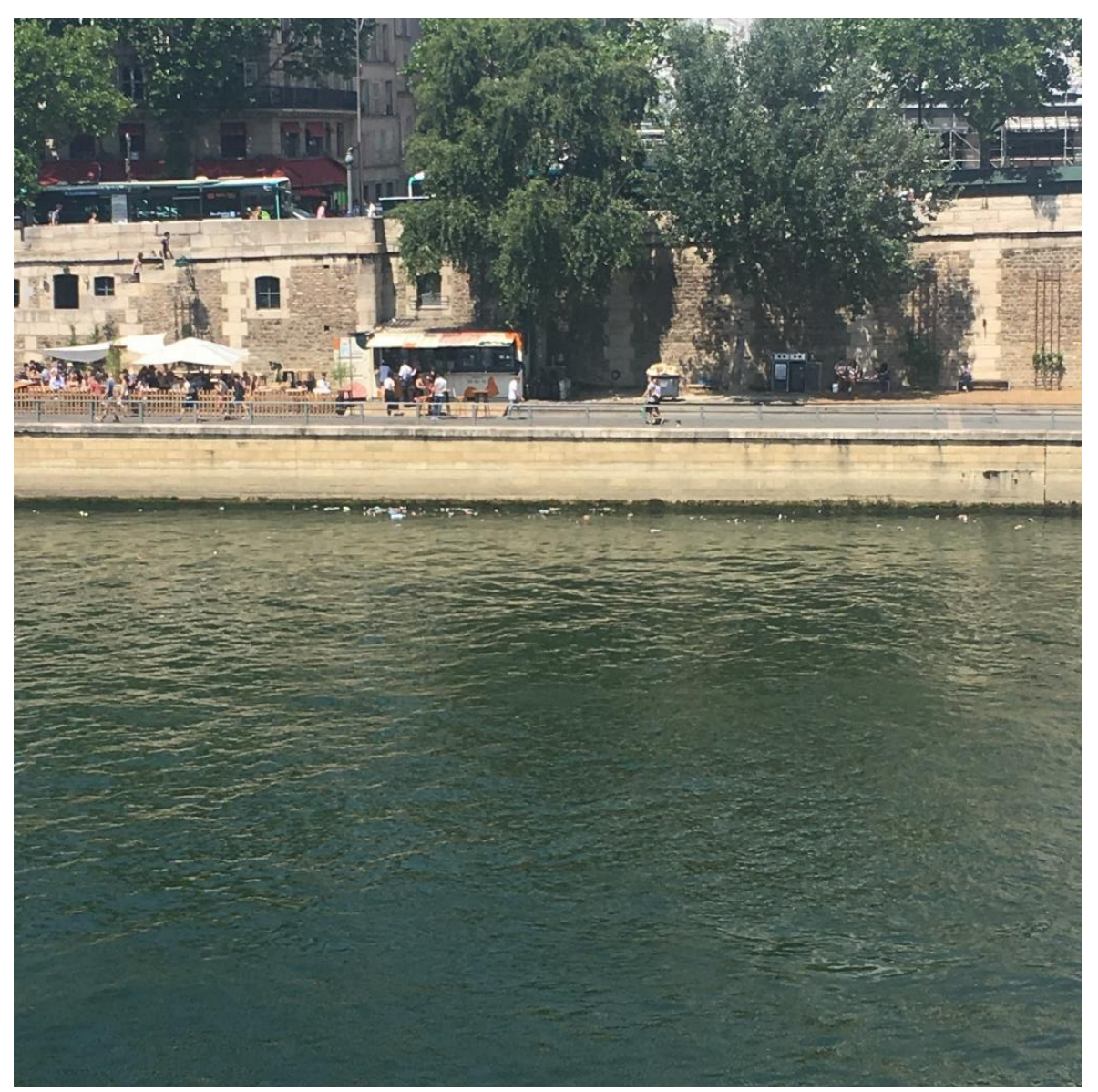




\section{Projectvoorstellen}

\section{Projectvoorstel}

1 Meettechniek waterkolom

2 Meettechniek sediment

3 Optimalisatie meettechniek rivieroever

4 Optimalisatie meettechniek drijvend

5 Nulmeting drijvend afval

6 Nulmeting waterkolom

7 Nulmeting sediment

8 Bepalen standaard meeteenheden

9 Ontwikkelen methode massabalans

10 Ontwikkelen methode emissie naar zee

11 Bepalen meest voorkomende materiaaltype

12 Langetermijnmonitoring drijvend afval

13 Langetermijnmonitoring drijvend waterkolom

14 Langetermijnmonitoring drijvend sediment

15 Integrale langetermijnmonitoring

16 Harmonisatie met buurregio's

17 Trendanalyses zwerfafval

18 Aantoonbaar effect maatregelen

19 Vaststellen grens-/streefwaarden

20 Opstellen massabalans

21 Bepalen emissies naar zee

22 Bepalen bronnen zwerfafval

23 Onderzoek rol van citizen science in monitoring

: Oever, D: Drijvend, S: Sediment

W: Waterkolom, B: Biota

\section{Compartiment Niveau Bouwt voort op Cluster}

Grote vragen

Urgent Belangrijk

Tijd/geld

Impact

\begin{tabular}{llll|c|c|c|} 
W & 1 & 1 & & Beleid & Operationeel & Kennis Oplossing
\end{tabular}

$\begin{array}{ll}4 & 4 \\ 3 & 3 \\ 4 & 5 \\ 5 & 5 \\ 5 & 5 \\ 4 & 4 \\ 3 & 3 \\ 5 & 5 \\ 4 & 4 \\ 3 & 4 \\ 4 & 3 \\ 2 & 4 \\ 2 & 3 \\ 1 & 2 \\ 1 & 5 \\ 1 & 4 \\ 2 & 4 \\ 3 & 5 \\ 4 & 5 \\ 3 & 4 \\ 4 & 4 \\ 3 & 4 \\ 3 & 4 \\ 3 & 4\end{array}$




\section{Prioriteren projecten}

De Routekaart gebruikt een simpele methode om concrete

projectvoorstellen te prioriteren. Dit wordt gedaan op basis van twee combinaties van scores. Ten eerste wordt elk project een score toebedeeld op de assen (1) belangrijk en (2) urgent. Op de as belangrijk wordt aangegeven hoe groot het belang is dat dit project wordt uitgevoegd. De as urgent geeft aan hoe snel het zou moeten worden uitgevoerd. Let op: de projecten zijn beoordeeld op basis van kennis en ervaring van de auteurs. De gebruikers van de Routekaart kunnen dit naar eigen inzicht aanpassen. Mogelijk heeft dit invloed op de prioritering en planning van projecten.

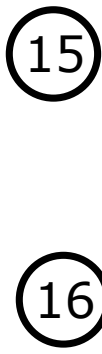

(18)

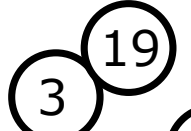

(20)

(7)

(2) (10)

(11)
(14)

(22)

(17)

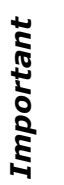

1 


\section{Prioriteren projecten}

Ten tweede wordt elk project gescoord op de assen (1)

tijd/kosten en (2) impact. Tijd/kosten geeft aan hoeveel middelen nodig zijn om het project uit te voeren. De impact geeft weer op het behalen van de gestelde doelen (en een combinatie daarvan). Let op: de projecten zijn beoordeeld op basis van kennis en ervaring van de auteurs. De gebruikers van de Routekaart kunnen dit naar eigen inzicht aanpassen. Mogelijk heeft dit invloed op de prioritering en planning van projecten.
(5)

(8)

(4)

(9)

1

22

(20) 21

(16) 6

(17)

है

(3) 


\section{Prioriteren projecten}

Het scoren van de projecten geeft inzicht in de prioriteit die projecten zijn moeten krijgen. Projecten die belangrijk en urgent zijn, met lage kosten en hoge impact moeten op de korte termijn worden uitgevoerd. Projecten die belangrijk en minder urgent zijn, en hoge impact hebben, maar hogere kosten hebben, kunnen het beste voor de lange termijn gepland worden. Projecten ie in andere kwadranten vallen hebben weinig prioriteit. We lichten een aantal projecten toe die hoge prioriteit hebben.

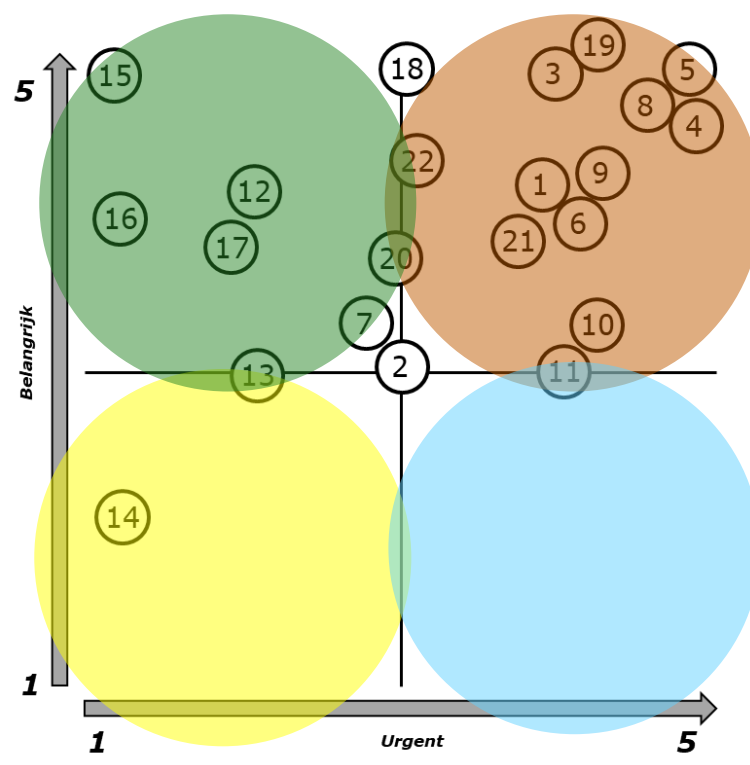

Belangrijk vs Urgent

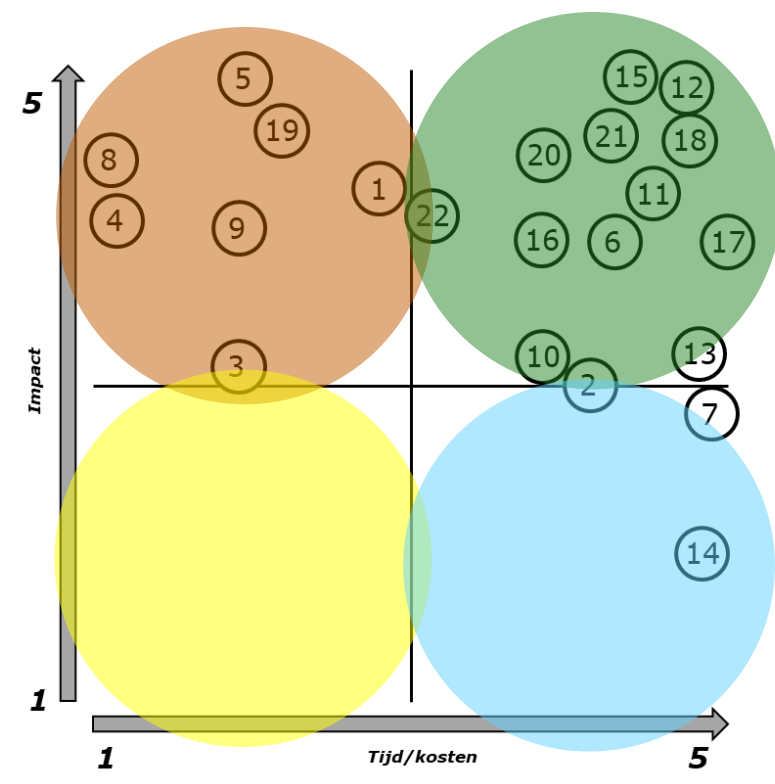

Tijd/kosten vs Impact
Prioriteit

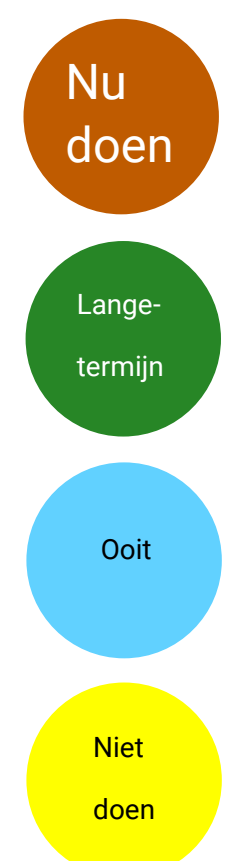




\section{Project 1: Nulmeting drijvend afval}

- Hoe: Telmetingen van bruggen op 10 locaties, verdeeld over Rijn, Waal, Maas en ljssel.

- Wanneer: Looptijd 1 jaar, metingen 2-4 keer per jaar per locatie, 30-120 minuten per meting.

- Wie: In-house (RWS) of delegeren (SDN, WUR).

- Vervolgprojecten na dit project:

- Massabalans, emissies (drijvend)

- $\quad$ Langetermijnmonitoring

- Vaststellen grens-/streefwaarden

- Referentieprojecten:

- $\quad$ RIMMEL (53 Europese rivieren)

- $\quad$ Schone Rivieren (oevermetingen)

O = observatie locatie

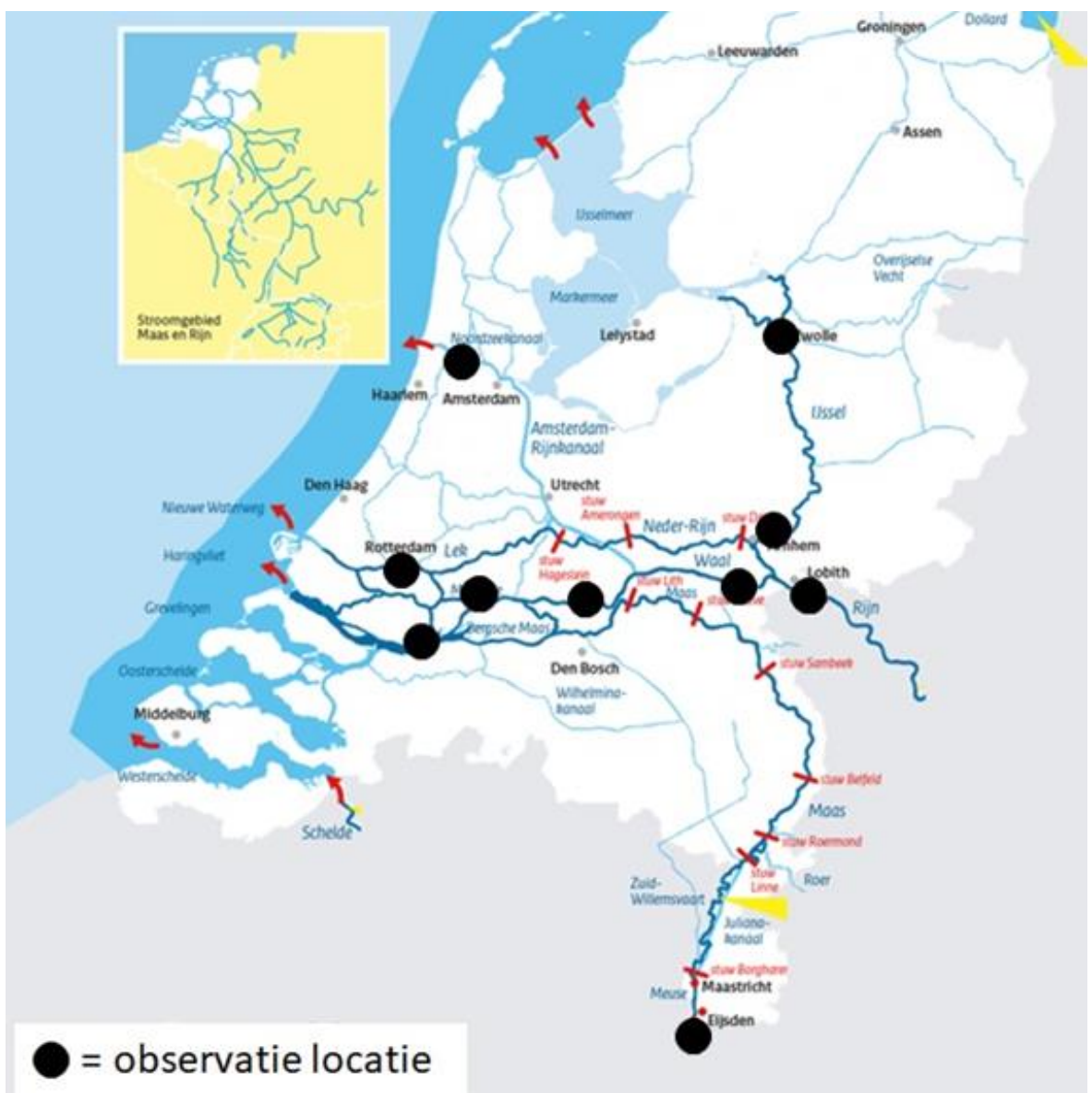




\section{Project 2: Meettechniek waterkolom}

- Hoe: Nieuwe ontwikkelingen Sonar/ADCP veelbelovend. Drie stappen

- Fundamentele experimenten in lab

- Gecontroleerd experiment in sluis Borgharen

- Testmetingen in natuurlijke omgeving (Nederrijn of Rijnmond)

- Wanneer: 1-jarig pilotproject om methode te testen

- Wie: Intern (RWS) of delegeren (WUR, TAUW)

- Vervolgprojecten na dit project

- Nulmetingen waterkolom

- Massabalans, emissie (waterkolom)

- Referentieprojecten

- $\quad$ Broere (2020), TU Delft \& WUR

\section{B. Sonar reflection}

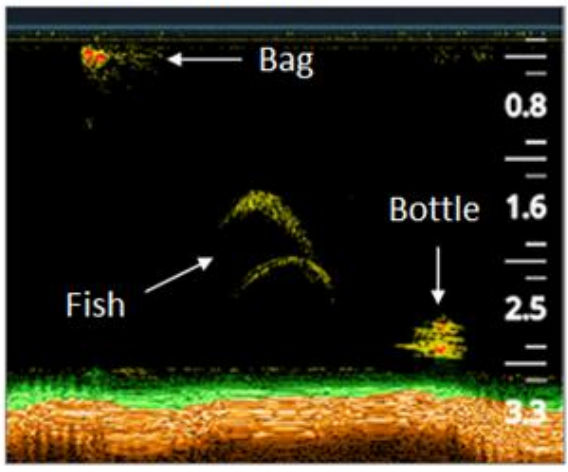

D. Experimental setups (1) and (2)

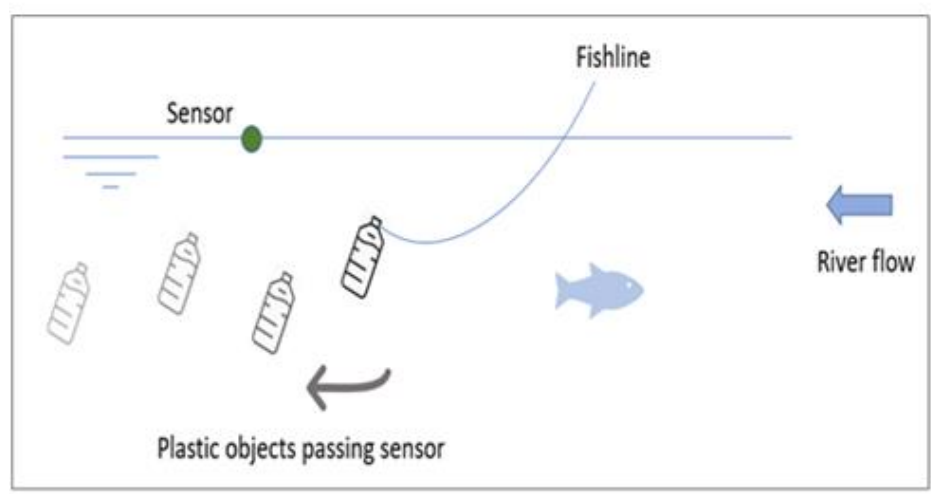

Guadalete river

Monitoring locations (1) 


\section{Project 3: Optimalisatie meettechniek rivieroever}

- Hoe: Verbeteren huidige Rivier-OSPAR-methode. Uitbreiden met metingen massa voorwerpen. Optimalisatie i.s.m. Schone Rivieren

- Wanneer: Projectduur 3-6 maanden

- Wie: Intern (RWS) of delegeren (SDN + Extern adviseur)

- Vervolgprojecten na dit project

- Nulmetingen rivieroever

- Massabalans, emissie (rivieroever)

- Referentieprojecten

- Van Emmerik et al. (2020), Evaluatie Rivier-OSPARmethode (WUR)

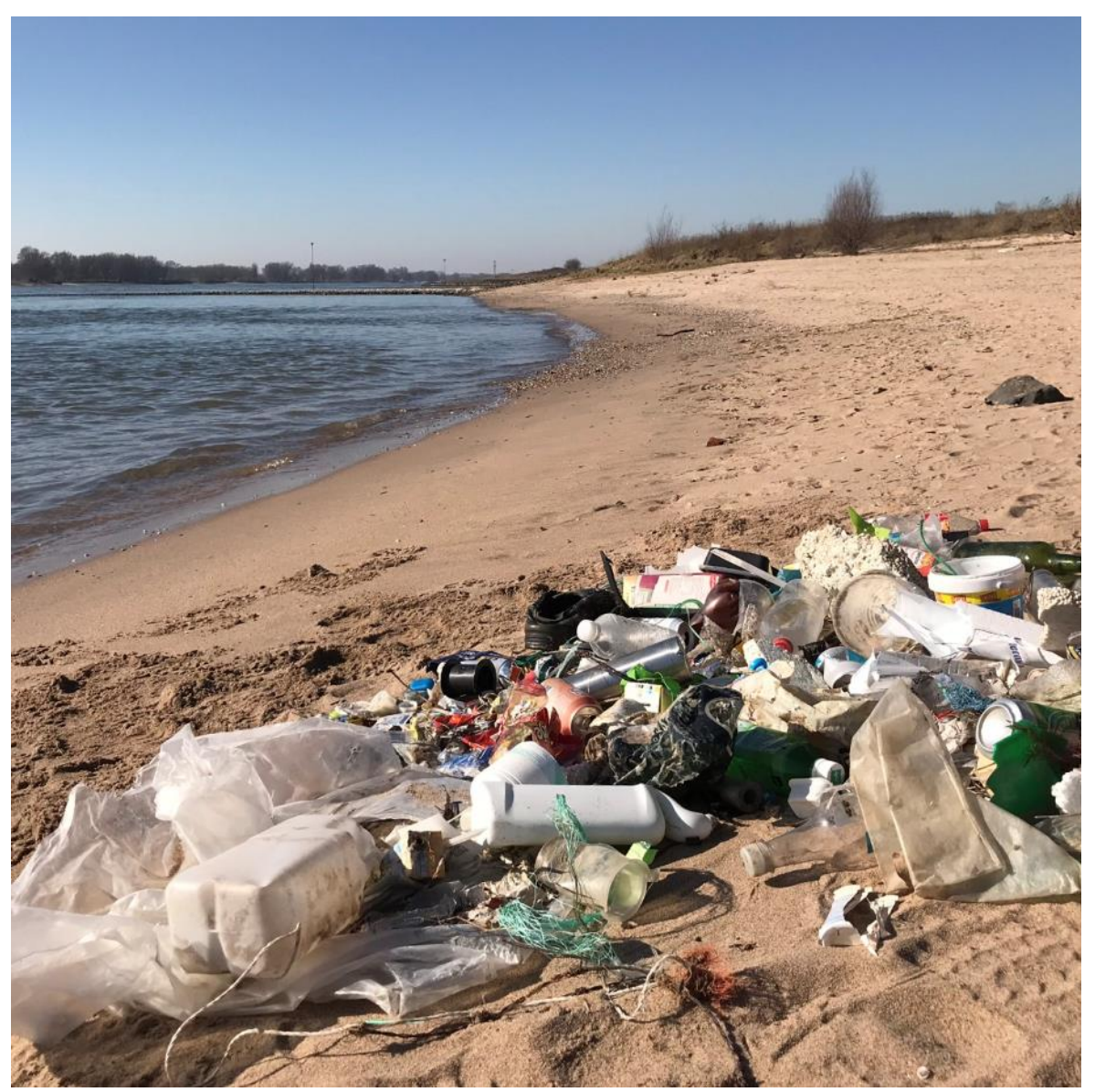

Bron: Stichting de Noordzee (2020) 


\section{Project 4: Integratie zwerfafval RWS- monitoring}

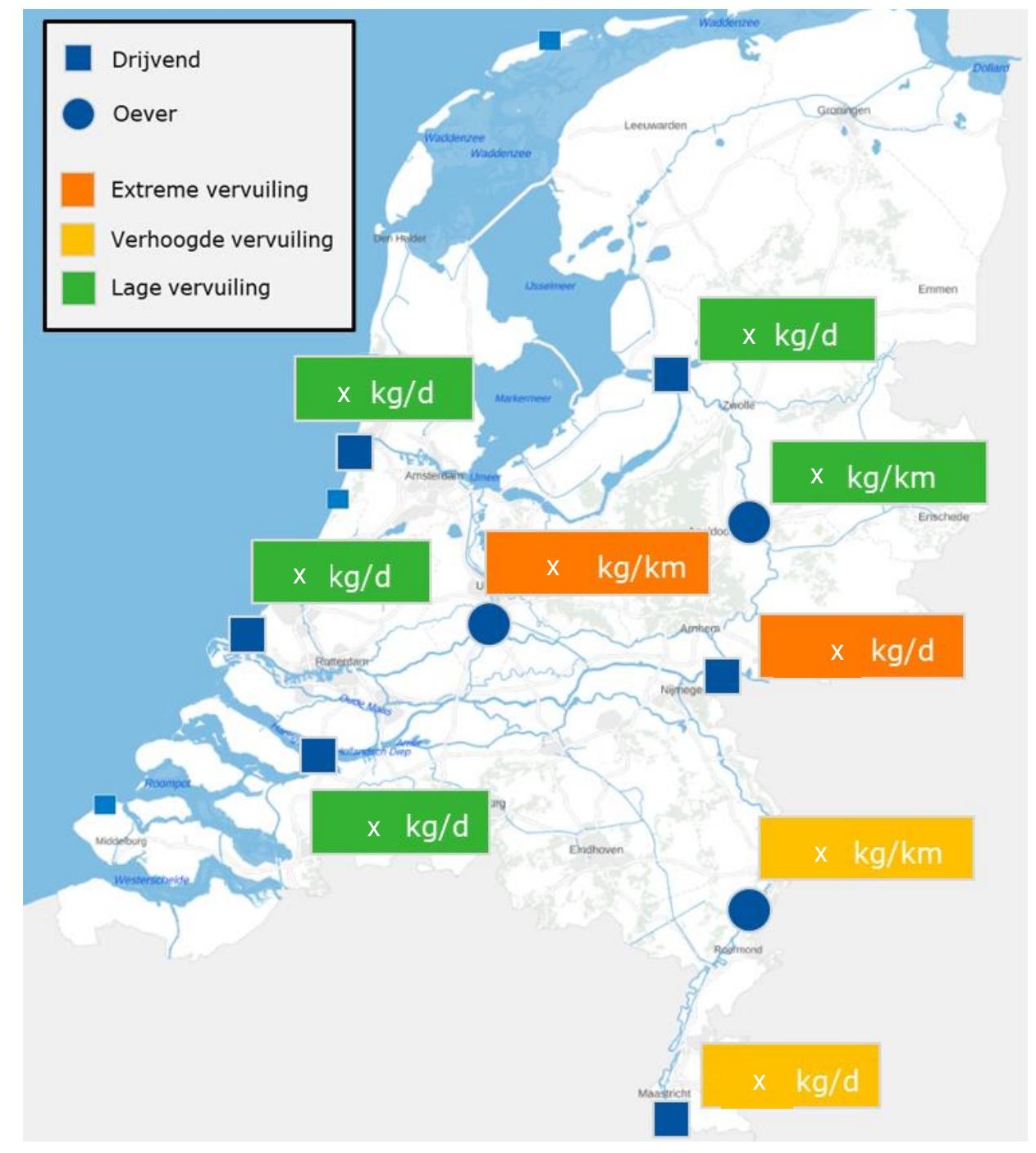




\section{Route naar de toekomst: Projectclusters}

Om het plannen en uitvoeren van individuele projecten overzichtelijker te maken, zijn alle projecten ondergebracht in clusters. De clusters delen gemeenschappelijke doelen en een aanpak, maar bieden flexibiliteit in de exacte breedte en diepte van de uit te voeren projecten. Afhankelijk van nieuwe inzichten en beschikbare middelen, kunnen specifieke projecten worden toegevoegd aan het cluster of juist worden verwijderd. De routekaart bestaat uit zes clusters:

1: Nieuwe Meettechnieken

2: Meetprotocollen

3: Nationale Nulmeting

4: Langetermijnmonitoring

5: Samenwerking \& Integratie

6: Richtlijnen \& Oplossingen

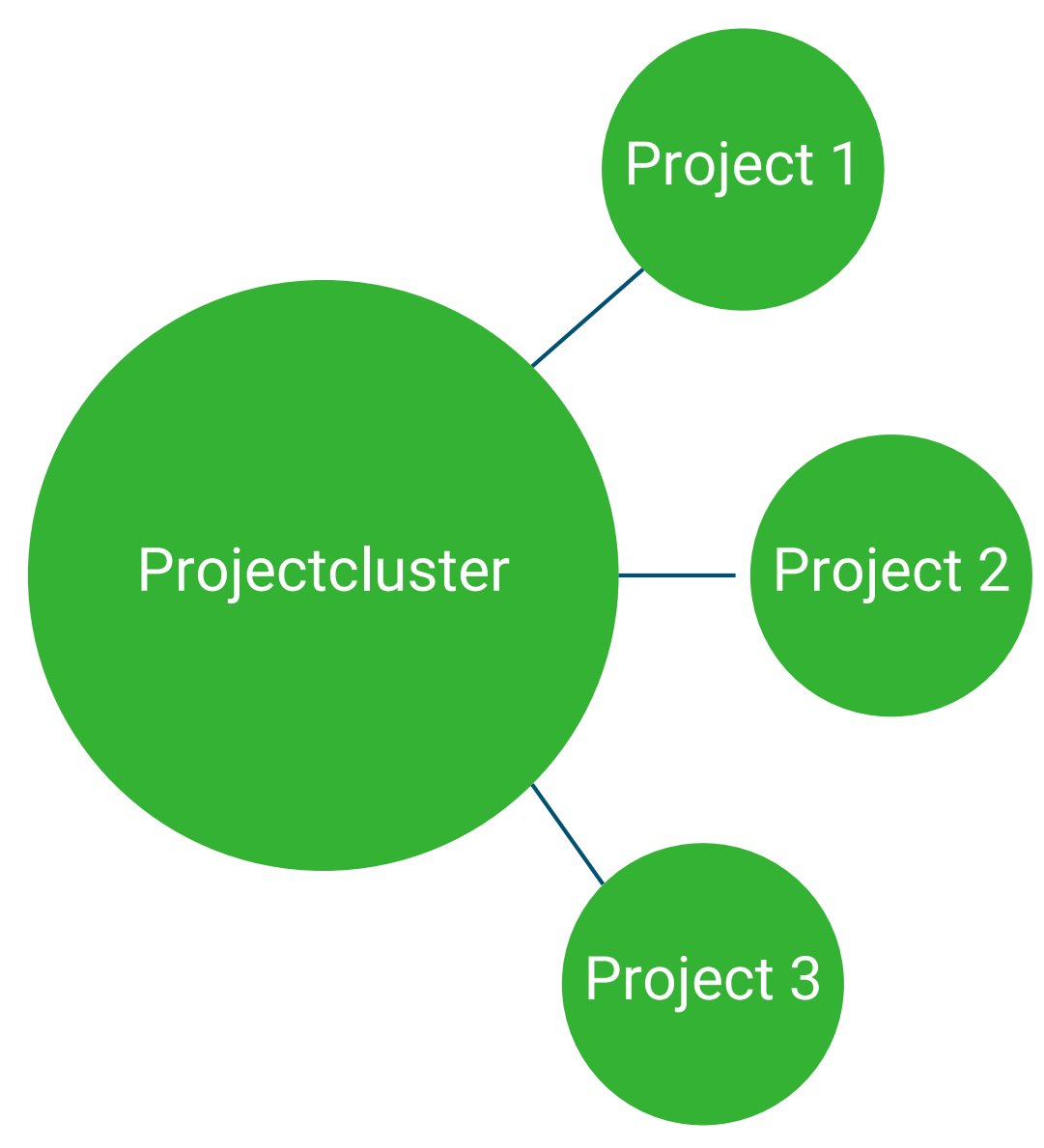




\section{Route naar de toekomst: Projectclusters}

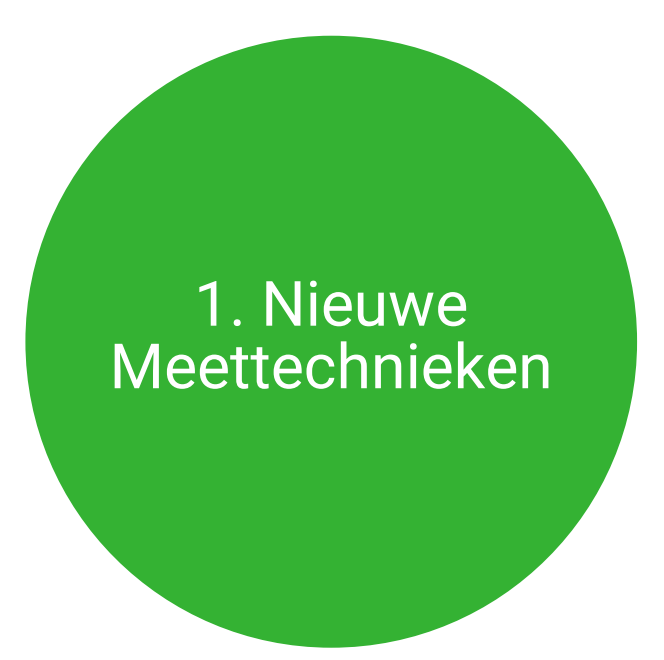

Doel:

(Door)ontwikkelen van (high-tech) meettechieken voor zwerfafval in verschillende riviercompartimenten.

Projecten in cluster:

o.a. (1) Meettechiek waterkolom, (2) meettechniek sediment, (3) optimalisatie meettechniek rivieroever.

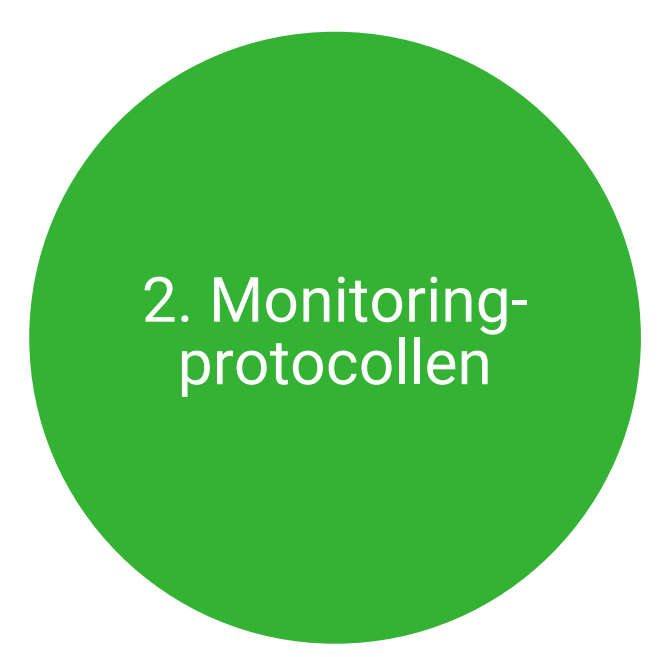

Doel:

Opstellen protocollen voor kwantitatieve monitoring door middel van meten, modeleren en statistiek.

Projecten in cluster:

o.a. (9) Ontwikkelen methode massabalans, (10)

ontwikkelen methode emissie naar zee, (11) bepalen meest voorkomende materiaaltype

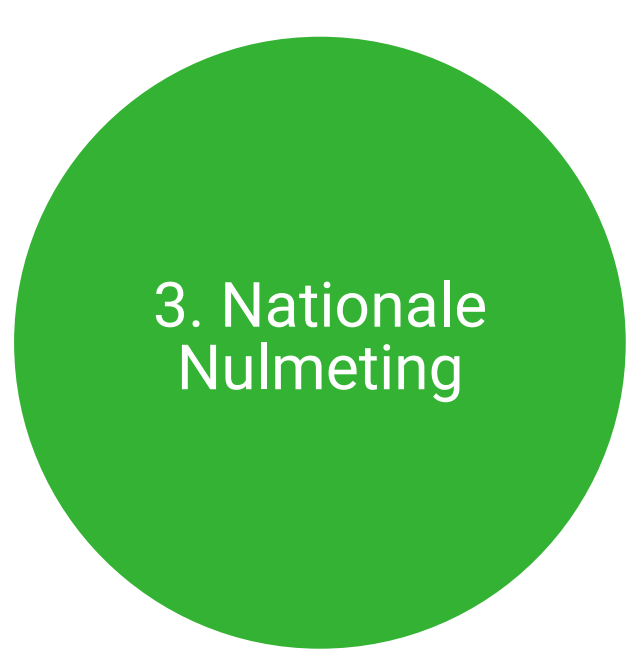

Doel:

Nulmeting in riviercompartimenten voor eerste kwantificatie zwerfafval.

\section{Projecten in cluster:}

o.a. (5) Nulmeting drijvend afval, (6) nulmeting waterkolom, (7) nulmeting sediment. 


\section{Route naar de toekomst: Projectclusters}

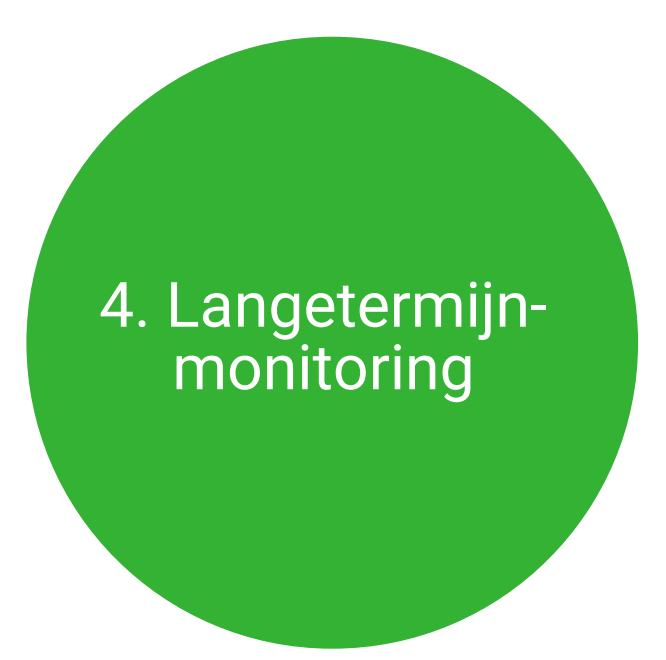

Doel:

Opzetten slimme langetermijnmonitoringstrategie.

\section{Projecten in cluster:}

o.a. $(9,10)$ Combinatie meten/modellen/statistiek voor

betrouwbare monitoring, $(12,13,14)$

Langetermijnmonitoring.

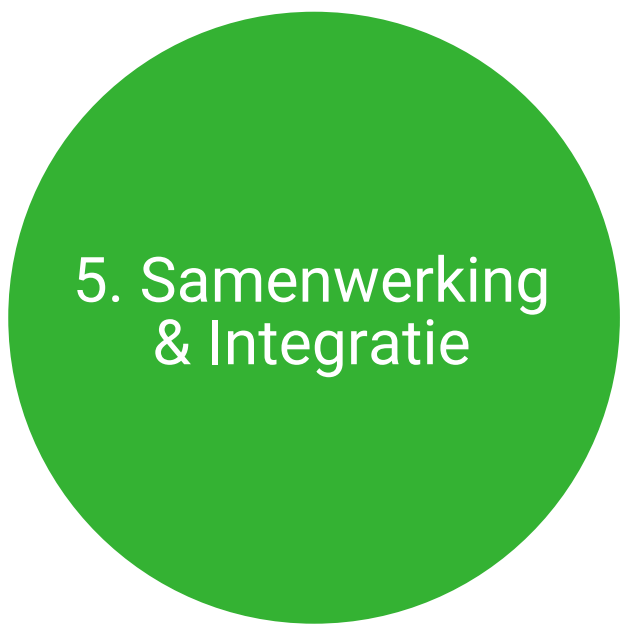

Doel:

Integreren monitoringsactiviteiten binnen Nederland en met buurregio's, op verschillende schalen (lokaal tot internationaal)

Projecten in cluster:

o.a. (15) Integratie zwerfafvalmonitoring in rivieren met MWTL, (16) samenwerking lokaal tot nationaal, internationale afstemming.

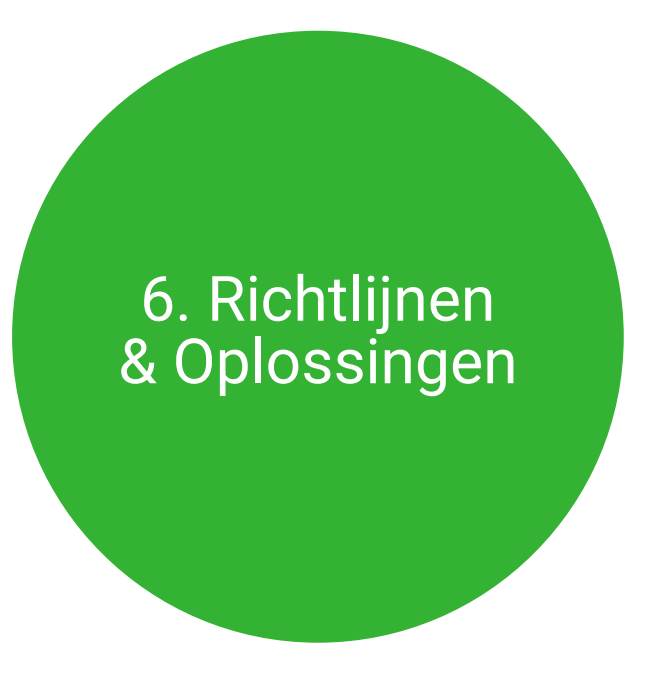

Doel:

Kwantitatief kunnen bepalen wat de staat van elke Nederlandse rivier, en de effectiviteit van maatregelen is.

\section{Projecten in cluste:}

o.a. (19) Vaststellen grens-/streefwaarden, (18) aantoonbaar effect maatregelen. 


\section{Wanneer wat doen?}

Het clusteren van projecten zorgt ervoor dat we eenvoudiger de grote lijnen van de volgende stappen kunnen uitzetten. Op de korte termijn, cluster 1 en 2 zullen de hoogste prioriteit hebben. Monitoring kan pas van start gaan zodra er geschikte methoden en protocollen ontwikkeld zijn. Op de middellange termijn kan de focus overgaan naar het uitvoeren van nationale nulmetingen van alle riviercompartimenten. Zodra dat gedaan is voor een compartiment kan begonnen worden met het plannen van langetermijnmonitoring. Ook moet tegen die tijd een begin gemaakt worden met clusters 5 en 6 . Voor de lange termijn zullen vooral clusters 4-6 relevant blijven voor het uitvoeren van trendanalyses en het evalueren van de effectiviteit van maatregelen.

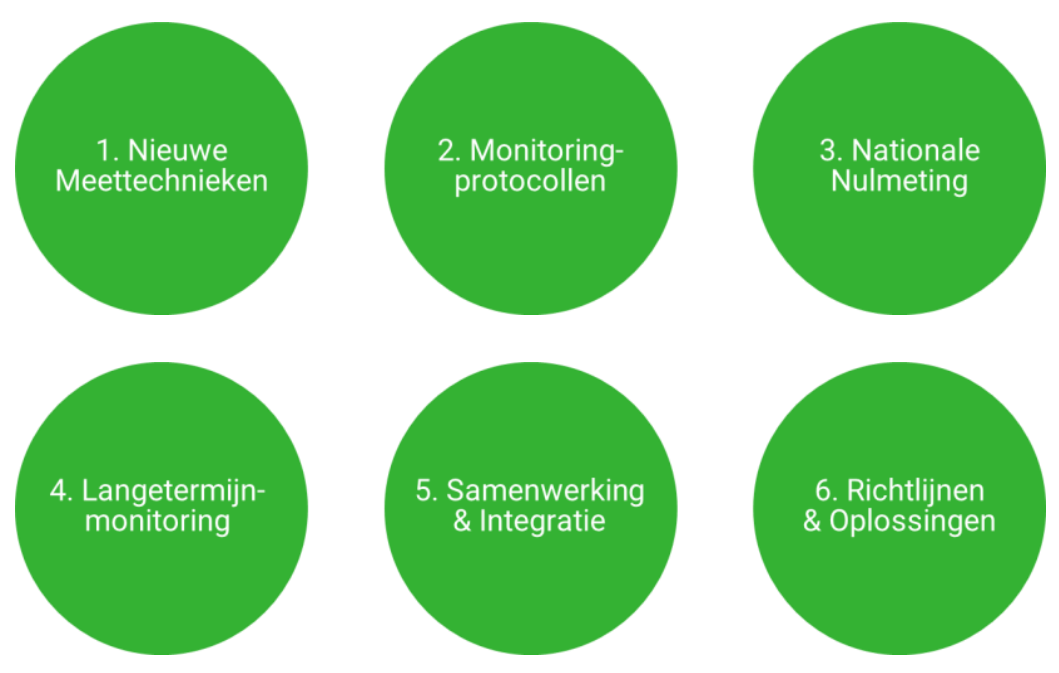




\section{Tijdlijn}

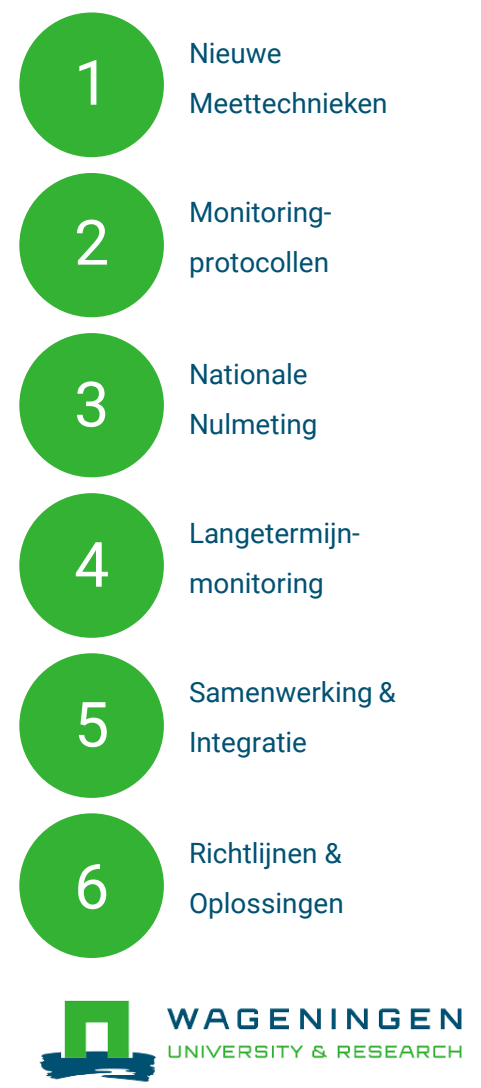

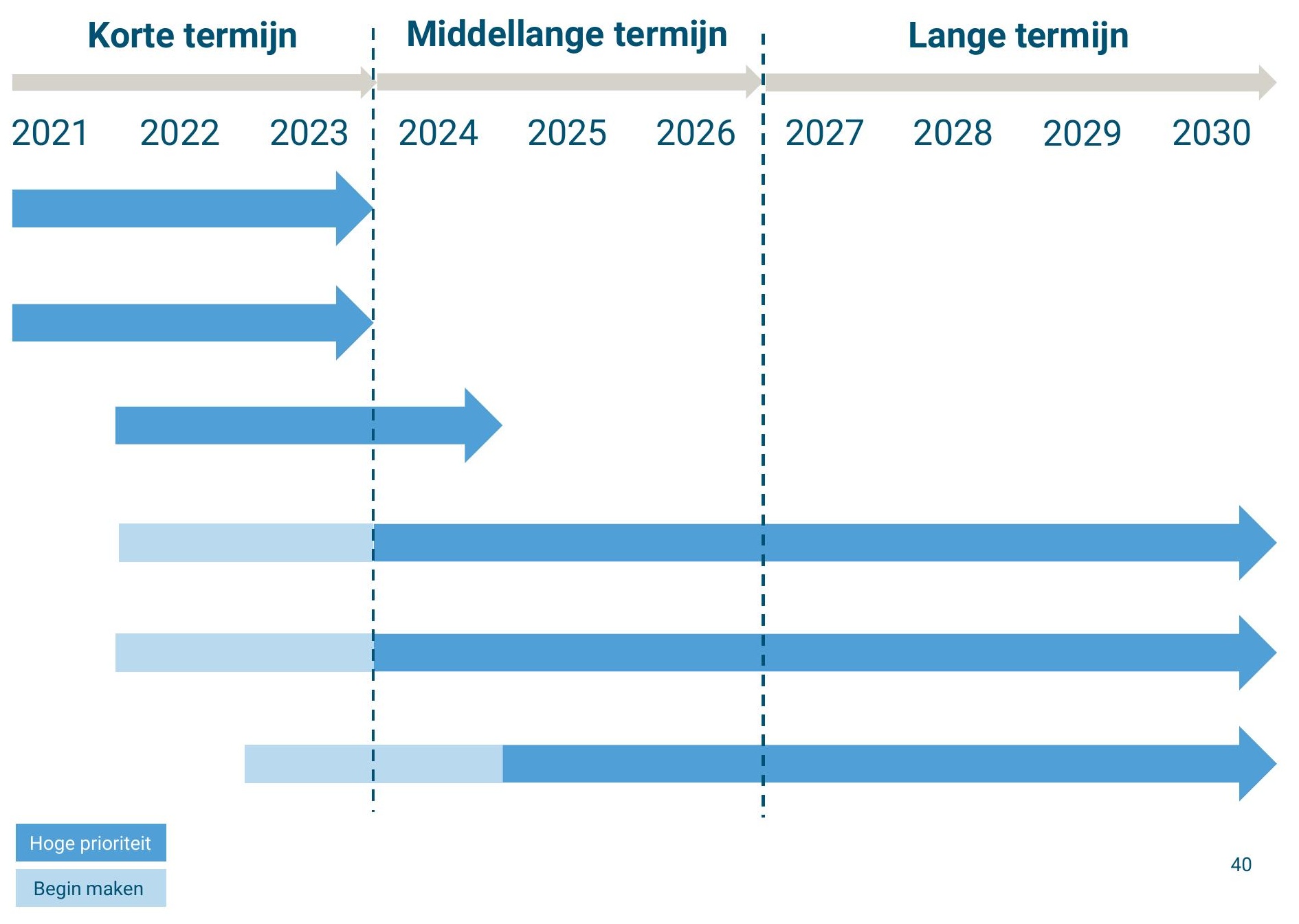




\section{De Routekaart als flexibel raamwerk}

De Routekaart is geen lineaire oplossing. Integendeel, het biedt een flexibel raamwerk waar plaats is voor nieuwe inzichten, doelen, prioriteiten en data. Zwerfafvalmonitoring vraagt om een iteratieve aanpak, en het belangrijkste is dat er een begin wordt gemaakt met de start van projecten die nu hoge prioriteit hebben. Wanneer nieuwe inzichten of antwoorden op vragen zijn verkregen, kan worden test of monitoringsdoelen zijn gehaald en of ze nog actueel zijn. Vervolgens kan een nieuwe cyclus worden gestart van doelen naar open vragen. Wederom kan de Routekaart worden gebruikt om routes van stand van zaken naar doel uit te stippelen. Op basis van op dat moment geldende context en middelen, kan de projectlijst opnieuw worden geprioriteerd, geclusterd en gepland. Hierna volgt de volgende iteratie.

\section{Tijdspad}

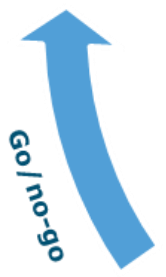

Prioriteit \& clusters
Doelen voor

monitoring

Beleid Kennis Beheer Oplossing

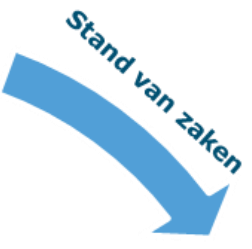

Grote

vragen

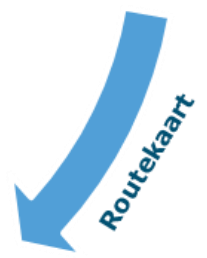

Routes naar

antwoorden 


\section{Samenvatting}

Zwerfafval in rivieren heeft een negatieve impact op mens en milieu. Een langetermijn monitoringstrategie zal bijdragen aan (1) beleid, (2) kennisontwikkeling, (3) operationele doelen en (4) evalueren van oplossingen. De Routekaart maakt de samenhang tussen doelen, openstaande vragen en projecten inzichtelijk, en helpt om concrete projecten te formuleren, prioriteren en evalueren. De Routekaart bestaat uit drie niveau's: (1) meettechnieken, (2) nulmetingen, en (3) langetermijnmetingen. Deze fundamentele ontwikkelingen voeden op hun beurt de antwoorden op de grote vragen.

Projectvoorstellen kunnen middels de Routekaart geprioriteerd worden, om een optimale volgorde van uitvoering te bepalen. De Routekaart kan aangepast worden naar aanleiding van nieuwe inzichten vanuit de grote vragen, nieuwe observaties, en technische ontwikkelingen. Door middel van een Dashboard kan direct inzichtelijk worden gemaakt hoe afgeronde projecten beschikbare methoden, kennis en kunde vergroten. De projecten gebundeld in zes clusters: Nieuwe Meettechieken, Meetprotocollen, Nationale Nulmeting, Langetermijnmonitoring, Samenwerking \& Integratie, en Richtlijnen \& Oplossingen. Specifieke projecten kunnen worden toegevoegd of verwijderd. De zes clusters zijn geplaatst op een tijdlijn als suggestie welke projecten prioriteit moeten krijgen op korte, middellange en lange termijn. De Routekaart is geen lineaire oplossing, maar biedt een flexibel raamwerk. Na nieuwe inzichten kan opnieuw de cyclus van doelvragen-routes-projecten-clustering-planning doorlopen worden. Ontwikkeling en optimalisatie van een nationale zwerfafvalmonitoringstrategie is een iteratief proces.
De Routekaart Zwerfafvalmonitoring Nederlandse rivieren

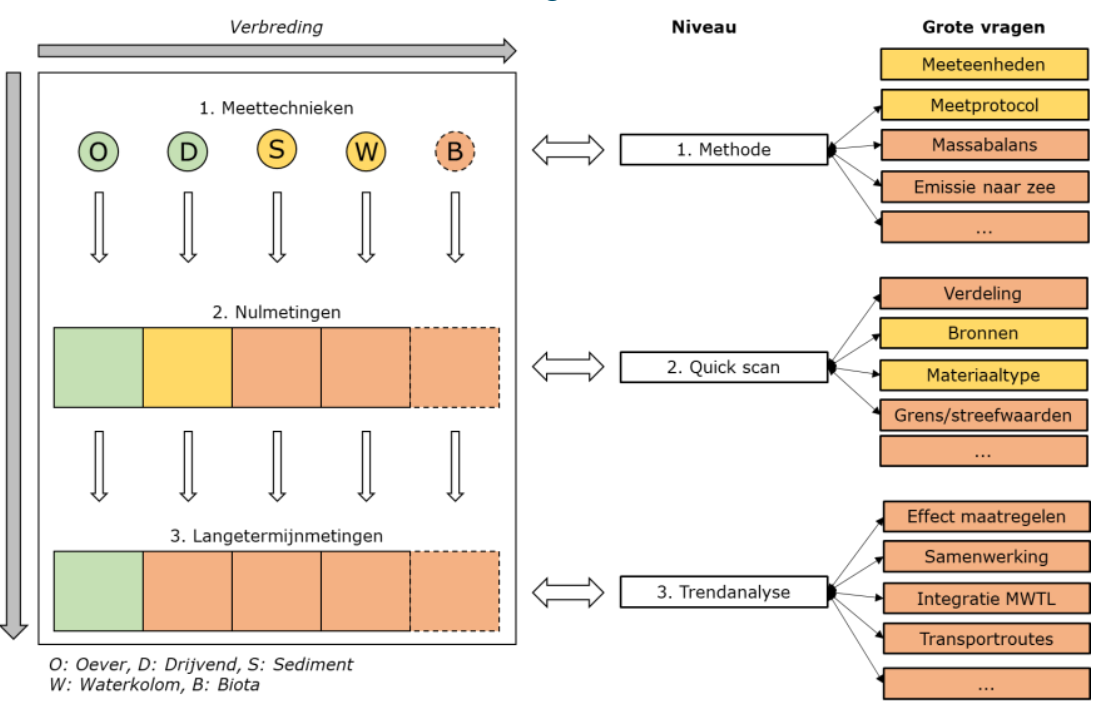

Over de Routekaart

De Routekaart maakt inzichtelijk hoe openstaande vragen en doelen in verband staan met het niveau van monitoring. Dit kan vervolgens gebruikt worden om projecten en acties te formuleren. Zo wordt duidelijk dat voor het kunnen doen van trendanalyses, langetermijnmetingen noodzakelijk zijn. Als deze nog niet beschikbaar zijn, zullen deze eerst gepland moeten worden. Hiervoor zijn echter eerst geschikte meettechnieken en nulmetingen nodig. In de Routekaart zijn verschillende riviercompartimenten opgenomen, omdat de huidige stand van zaken en benodigde stappen hier tussen kunnen verschillen. 


\section{Literatuur}

1. Broere, S. (2020). The sound of plastic: A proof-of-concept for detecting suspended riverine macroplastics with echo sounding. Delft University of Technology

2. De Vries, S. \& van't Hoff, V. (2020). Classificatie van verschillende zwerfafvalmonitoringsinitiatieven in de Nederlandse stroomgebieden. PULSAQUA.

3. Deloitte (2020). The price tag of plastic pollution An economic assessment of river plastic, available online [https://www2.deloitte.com/nl/nl/pages/strategy-analytics-and-ma/articles/the-price-tag-of-plasticpollution.html]

4. González-Fernández, D., Hanke, G., Kideys, A., Navarro-Ortega, A., Sanchez-Vidal, A., Brugère, A., ... \& Barcelo, D. (2018). Floating Macro Litter in European Rivers-Top Items. European Commission-DG Joint Research Centre.

5. Honingh, D., van Emmerik, T., Uijttewaal, W., Kardhana, H., Hoes, O., \& van de Giesen, N. (2020). Urban river water level increase through plastic waste accumulation at a rack structure. Frontiers in Earth Science, 8, 28

6. Kiessling, T., Knickmeier, K., Kruse, K., Brennecke, D., Nauendorf, A., \& Thiel, M. (2019). Plastic Pirates sample litter at rivers in Germany-Riverside litter and litter sources estimated by schoolchildren. Environmental Pollution, 245, 545-557

7. Lebreton, L. C., Van Der Zwet, J., Damsteeg, J. W., Slat, B., Andrady, A., \& Reisser, J. (2017). River plastic emissions to the world's oceans. Nature communications, 8,15611 .

WAGENINGEN

UNIVERSITY \& RESEARCH
8. Mcllgorm, A., Campbell, H. F., \& Rule, M. J. (2011). The economic cost and control of marine debris damage in the Asia-Pacific region. Ocean \& Coastal Management, 54(9), 643-651.

9. Meijer, L. J. J., van Emmerik, T., Lebreton, L., Schmidt, C., \& van der Ent, R. (2019). Over 1000 rivers accountable for $80 \%$ of global riverine plastic emissions into the ocean.

10. Schöneich-Argent, R. I., Dau, K., \& Freund, H. (2020). Wasting the North Sea?-A field-based assessment of anthropogenic macrolitter loads and emission rates of three German tributaries. Environmental Pollution 114367.

11. van der Wal, M, et al. "SFRA0025: identification and assessment of riverine input of (marine) litter." Report for Michail Papadoyannakis, DG Environment, United Kingdom (2015): 186.

12. Van Franeker, J. A., \& Kühn, S. (2019). Fulmar Litter EcoQO monitoring in the Netherlands: update 2018 (No C077/19). Wageningen Marine Research.

13. van Emmerik, T., Roebroek, C. T. J., de Winter, W., Vriend, P., Boonstra, M., \& Hougee, M. (2020). Riverbank macrolitter in the Dutch Rhine-Meuse delta. Environmental Research Letters.

14. van Emmerik, T., \& Schwarz, A. (2020). Plastic debris in rivers. Wiley Interdisciplinary Reviews: Water, 7(1), e1398.

15. van Wijnen, J., Ragas, A. M., \& Kroeze, C. (2019). Modelling global river export of microplastics to the marine environment: Sources and future trends. Science of the total environment, 673, 392-401.

16. Vriend, P., Van Calcar, C., Kooi, M., Landman, H., Pikaar, R., \& Van Emmerik, T. (2020). Rapid assessment of floating macroplastic transport in the Rhine. Frontiers in Marine Science, 7, 10. 


\section{Routekaart Zwerfafvalmonitoring Nederlandse rivieren - Projectvoorstellen}

Tim van Emmerik, Paul Vriend

Hydrologie \& Kwantitatief Waterbeheer, Wageningen University
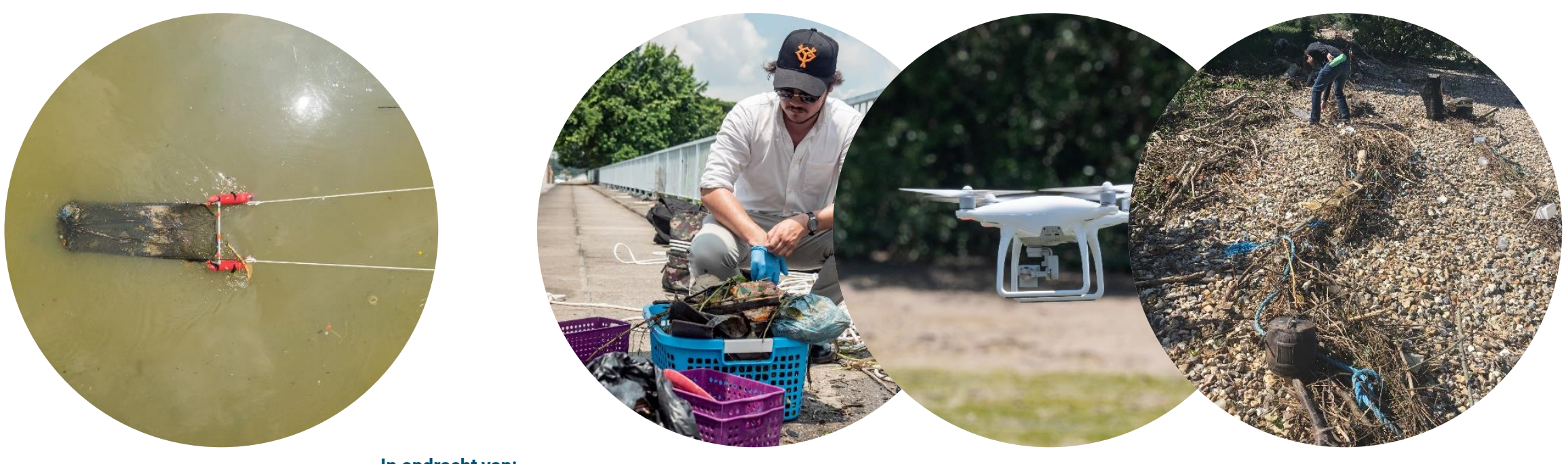


\section{Projectvoorstellen}

\section{Projectvoorstel}

1 Meettechniek waterkolom

2 Meettechniek sediment

3 Optimalisatie meettechniek rivieroever

4 Optimalisatie meettechniek drijvend

5 Nulmeting drijvend afval

6 Nulmeting waterkolom

7 Nulmeting sediment

8 Bepalen standaard meeteenheden

9 Ontwikkelen methode massabalans

10 Ontwikkelen methode emissie naar zee

11 Bepalen meest voorkomende materiaaltype

12 Langetermijnmonitoring drijvend afval

13 Langetermijnmonitoring drijvend waterkolom

14 Langetermijnmonitoring drijvend sediment

15 Integrale langetermijnmonitoring

16 Harmonisatie met buurregio's

17 Trendanalyses zwerfafval

18 Aantoonbaar effect maatregelen

19 Vaststellen grens-/streefwaarden

20 Opstellen massabalans

21 Bepalen emissies naar zee

22 Bepalen bronnen zwerfafval

23 Onderzoek rol van citizen science in monitoring

24 Gebruikmaken alternatieve databronnen voor monitoring
Niveau Bouwt voort op

Beleid

1
1

1

1
2

2

2

1

1
1

2

3

3

3

3

3

3

2

2

1

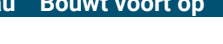

$1,2,3,4$

9

$5,6,7$

$5,6,7$

$5,6,7$

$5,6,7$

$12,13,14$

15

$12,13,14,15$

17

$5,6,7$

$5,6,7,9$

$5,6,7,10,20$

$5,6,7$
4
1
2

$x$
$x$
$x$
$x$
$x$
$x$
$x$
$x$
$x$
$x$

$x$
$x$
$x$
$x$
$x$
$x$
$x$
$x$
$x$
$x$
$x$
$x$
$x$

$x$
Operationeel

$$
x
$$

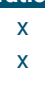

Kennis

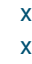

$x$
$x$

$\mathrm{x}$

$\mathrm{x}$

$\mathrm{x}$

$x$

$\mathrm{x}$

$x-x$
Oplossing

Urgent

Belangri

3

4

4

3

4

3

$x$ 


\section{Project 1}

\section{Nulmeting drijvend afval}

- Hoe: Telmetingen van bruggen op 10 locaties, verdeeld over Rijn, Waal, Maas en ljssel.

- Wanneer: Looptijd 1 jaar, metingen 2-4 keer per jaar per locatie, 30-120 minuten per meting.

- Wie: In-house (RWS) of delegeren (SDN, WUR).

- Vervolgprojecten na dit project:

- Massabalans, emissies (drijvend)

- Langetermijnmonitoring

- Vaststellen grens-/streefwaarden

- Referentieprojecten:

- $\quad$ RIMMEL (53 Europese rivieren)

- $\quad$ Schone Rivieren (oevermetingen)

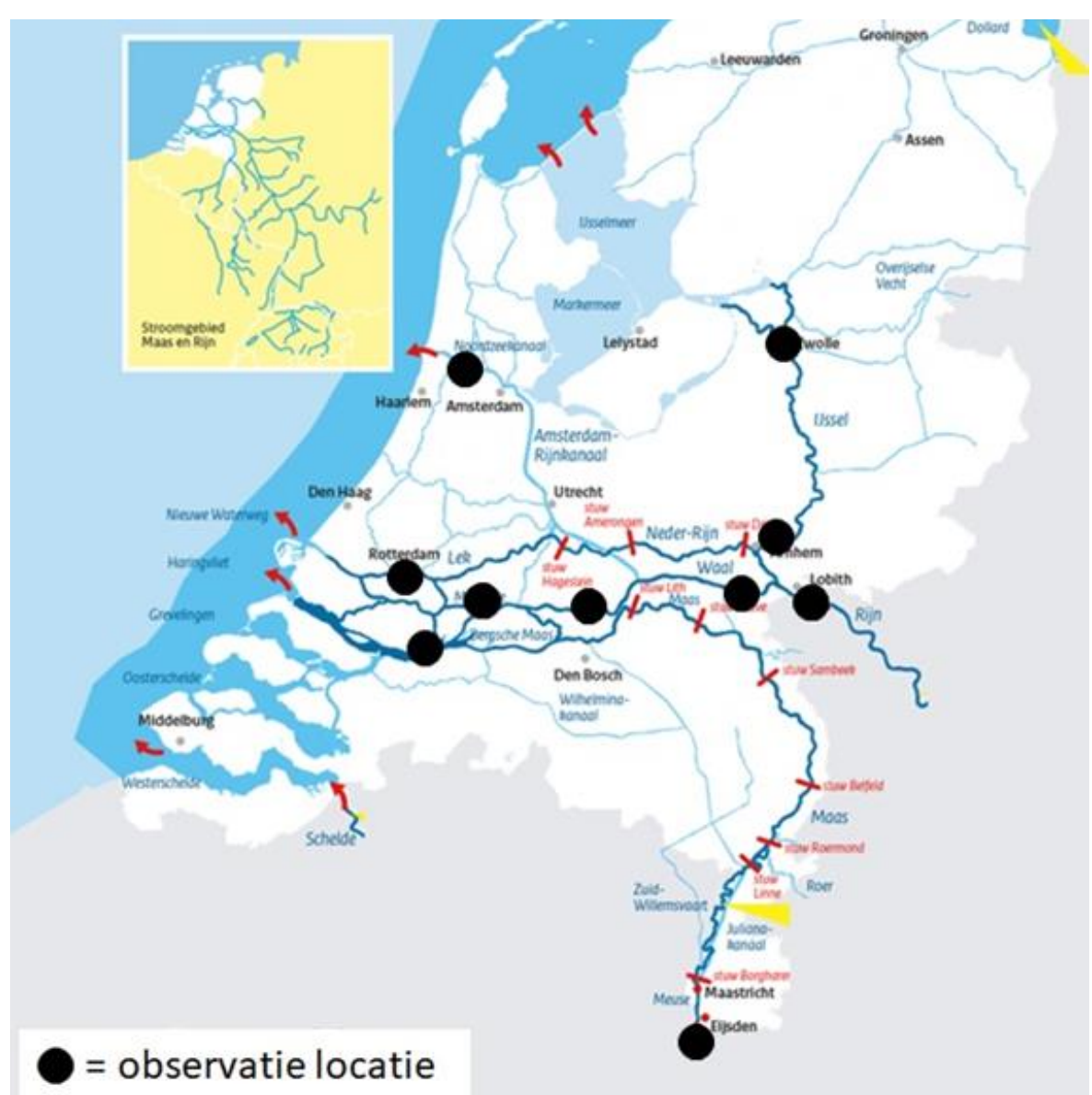




\section{Project 2}

\section{B. Sonar reflection}

\section{Meettechniek waterkolom}

- Hoe: Nieuwe ontwikkelingen Sonar/ADCP veelbelovend. Drie stappen

- Fundamentele experimenten in lab

- Gecontroleerd experiment in sluis Borgharen

- Proof-of-concept-metingen in natuurlijke omgeving (Nederrijn of Rijnmond)

- Wanneer: 1-jarig pilotproject om methode te testen

- Wie: In-house (RWS) of delegeren (WUR, TAUW)

- Vervolgprojecten na dit project

- Nulmetingen waterkolom

- Massabalans, emissie (waterkolom)

- Referentieprojecten

$$
\text { - Broere (2020), TU Delft \& WUR }
$$

\section{Experimental setups (1) and (2)}

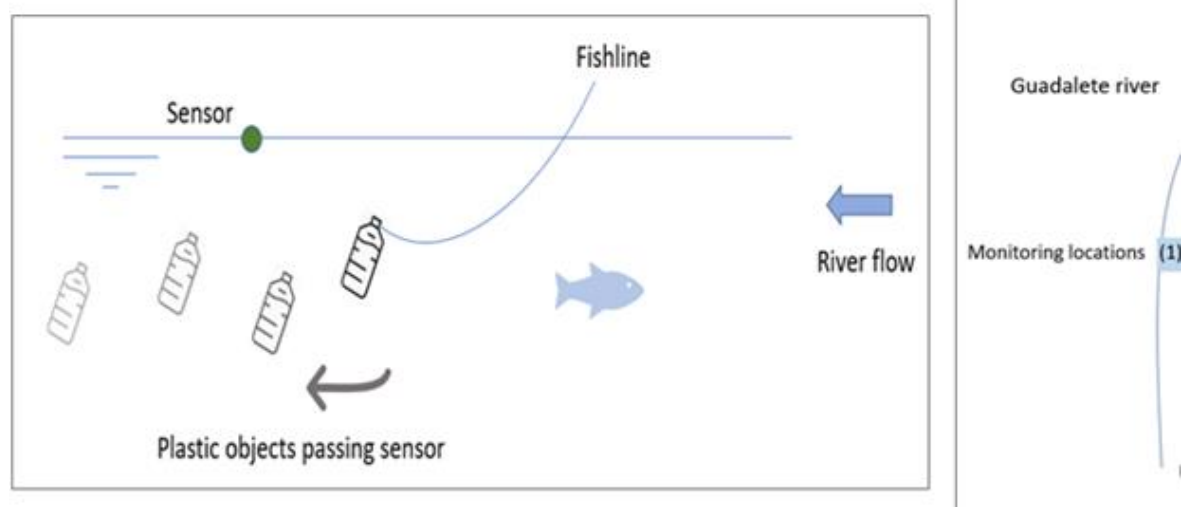




\section{Project 3}

\section{Optimalisatie meettechniek rivieroever}

- Hoe: Verbeteren huidige Rivier-OSPAR-methode. Uitbreiden met metingen massa voorwerpen. Optimalisatie i.s.m. Schone Rivieren

- Wanneer: Projectduur 3-6 maanden

- Wie: Delegeren (SDN + Extern adviseur)

- Vervolgprojecten na dit project

- Nulmetingen rivieroever

- Massabalans, emissie (rivieroever)

- Referentieprojecten

- Van Emmerik et al. (2020), Evaluation River-OSPAR method (WUR)

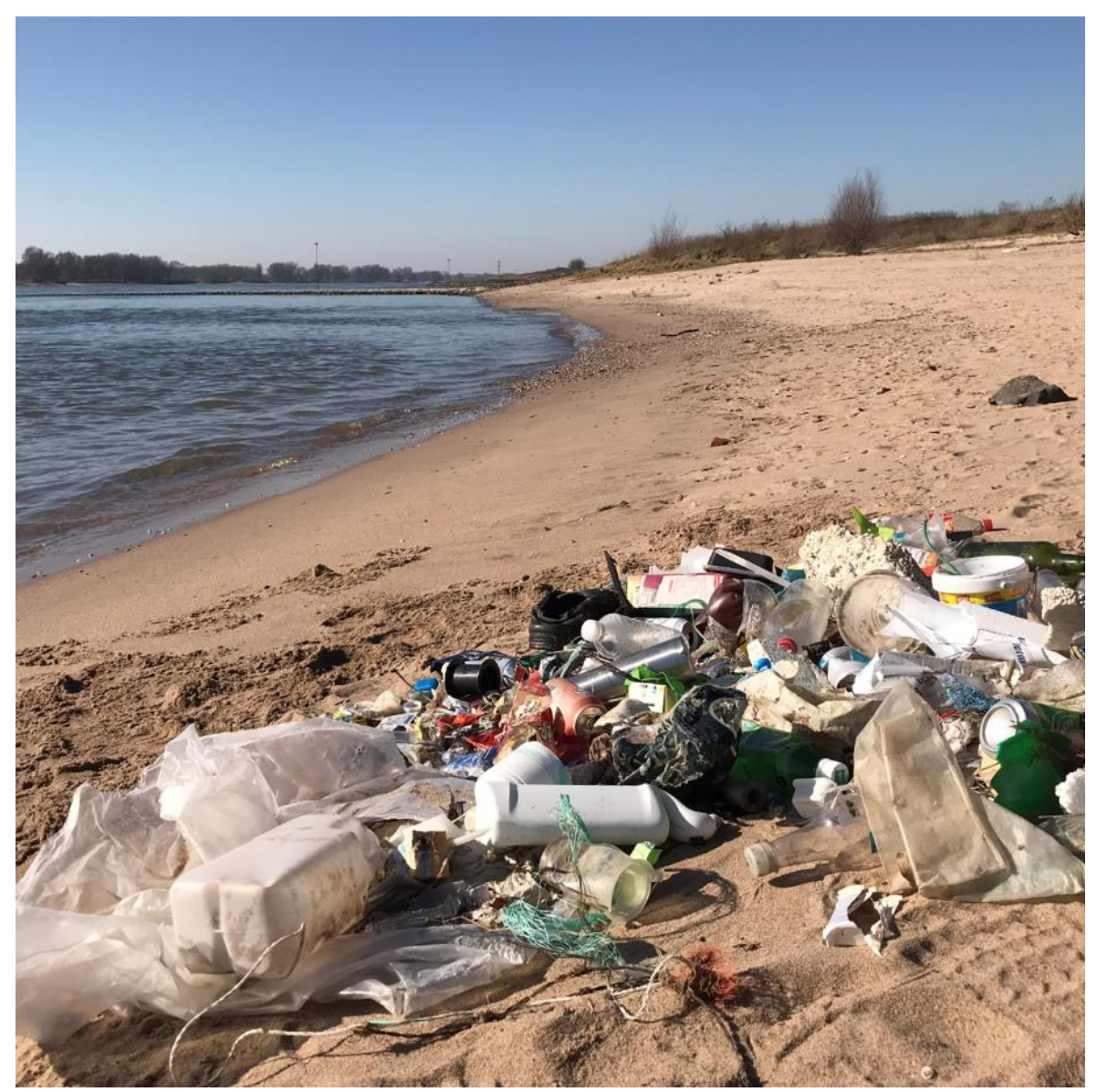

Bron: Stichting de Noordzee (2020) 


\section{Project 4}

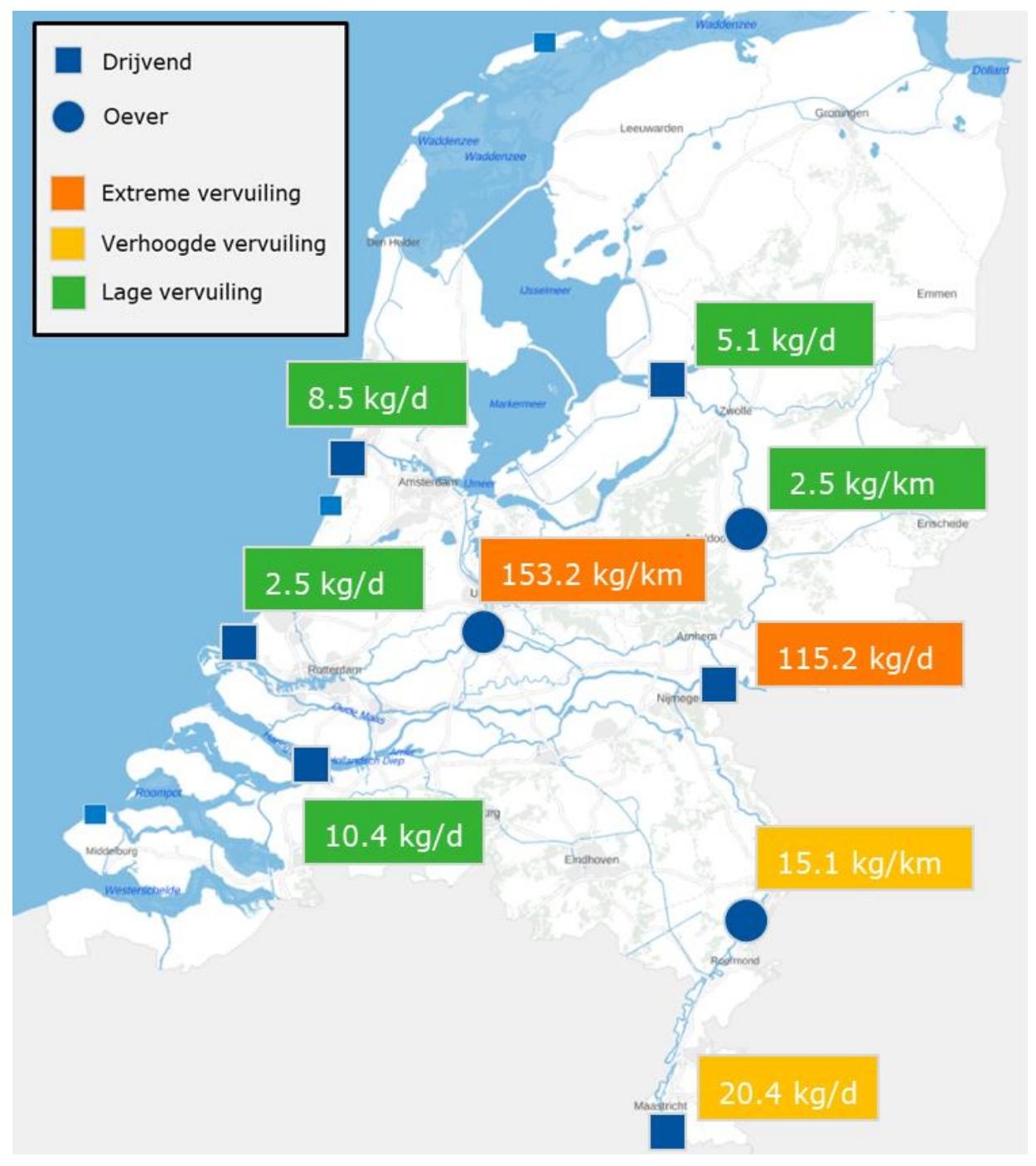




\section{Project 5}

\section{Onderzoek rol van citizen science in monitoring}

- Hoe: Onderzoeken hoe RWS citizen science kan integreren in de monitoringsstrategie door middel van vergelijkend onderzoek met referentieprojecten die citizen science gebruiken

- Wanneer: Projectduur 6 maanden

- Wie: In-house (RWS) of delegeren (SDN, WUR)

- Vervolgprojecten na dit project

- Integratie in alle monitoring

- Referentieprojecten

- Schone Rivieren

- Plastic Piraten (Duitsland)

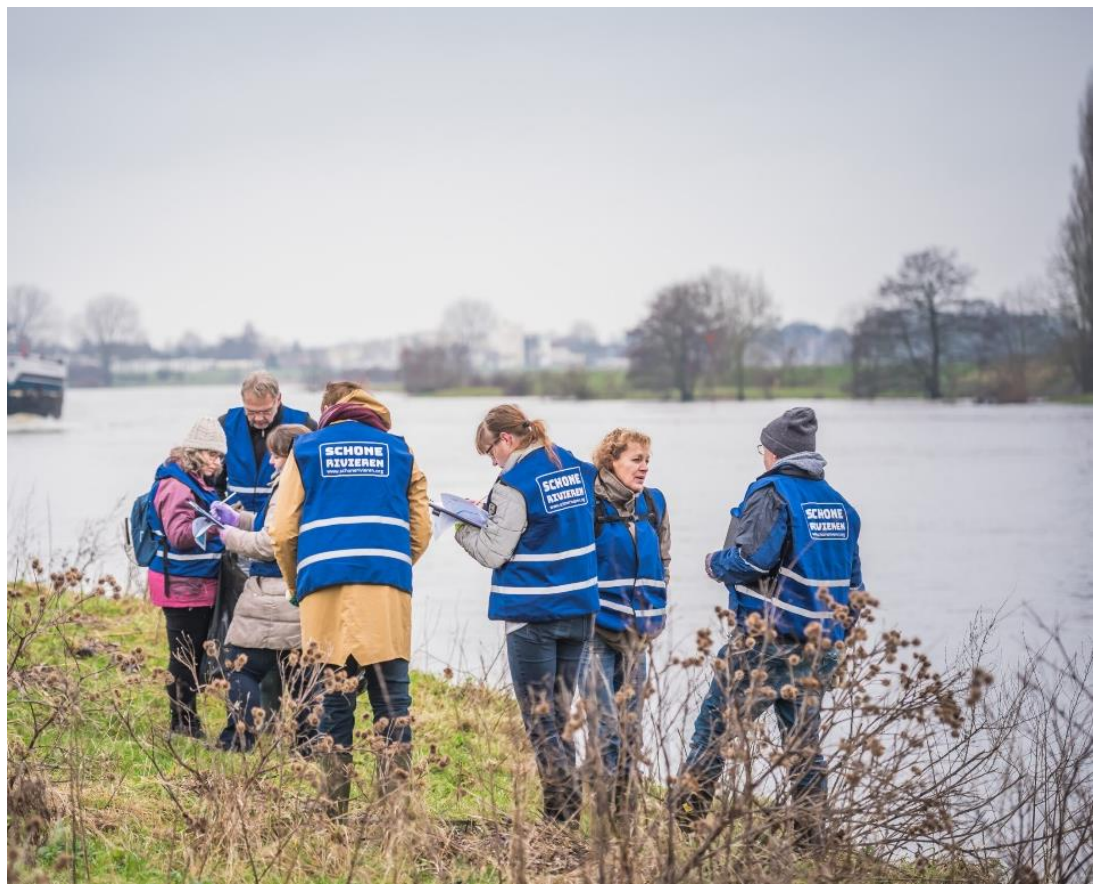

Bron: Stichting de Noordzee (2020) 


\section{Project 6}

\section{Gebruikmaken alternatieve bronnen voor monitoring}

- Hoe: Onderzoeken of alternatieve bronnen kunnen worden gebruikt voor monitoring zwerfafval. Denk bijvoorbeeld aan riool overstort data of rivierafvoer data om zwerfvuil transport te voorspellen.

- Wanneer: Projectduur 6 maanden

- Wie: In-house (RWS) en mogelijk partners die data verzamelen

- Vervolgprojecten na dit project

- Integratie in alle monitoring

- Referentieprojecten

- Van Emmerik et al. (2020), Evaluation River-OSPAR method (WUR)

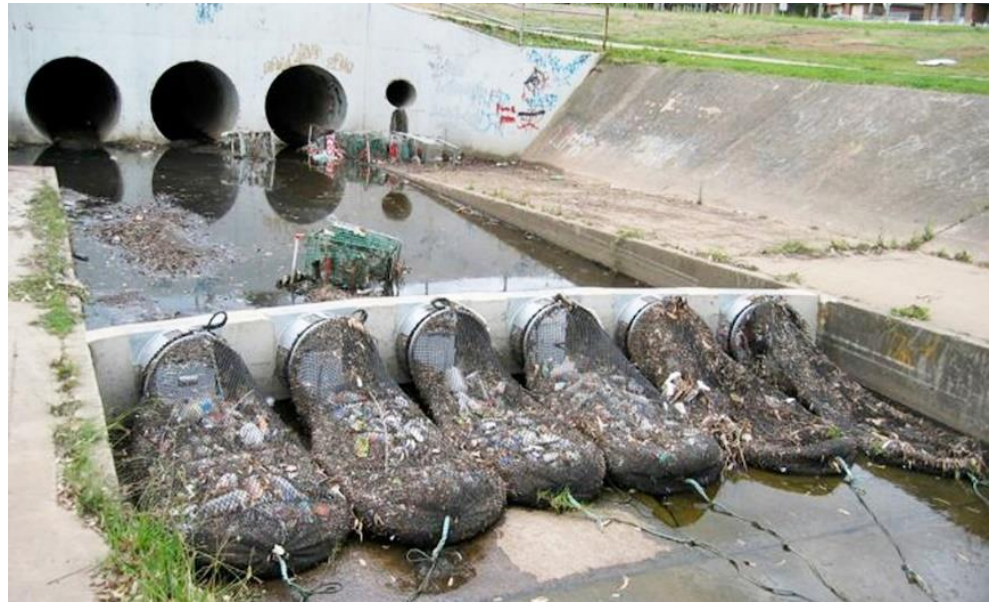

Riooloverstort in Amerika. Bron: Stormwatersystems 


\section{Project 7}

\section{Bepalen meest voorkomende materiaaltypen}

- Hoe: Analyseren van data verzameld tijdens nulmetingen in alle riviercompartimenten.

- Wanneer: Projectduur 1 - 3 jaar

- Wie: In-house (RWS)

- Vervolgprojecten na dit project

- Bepalen van mogelijke bronnen zwerfvuil

- Eerste indicatie voor gerichte aanpak

- Referentieprojecten

- RIMMEL project

- van Emmerik et al. (2020), Riverbank macrolitter in the Dutch Rhine-Meuse delta

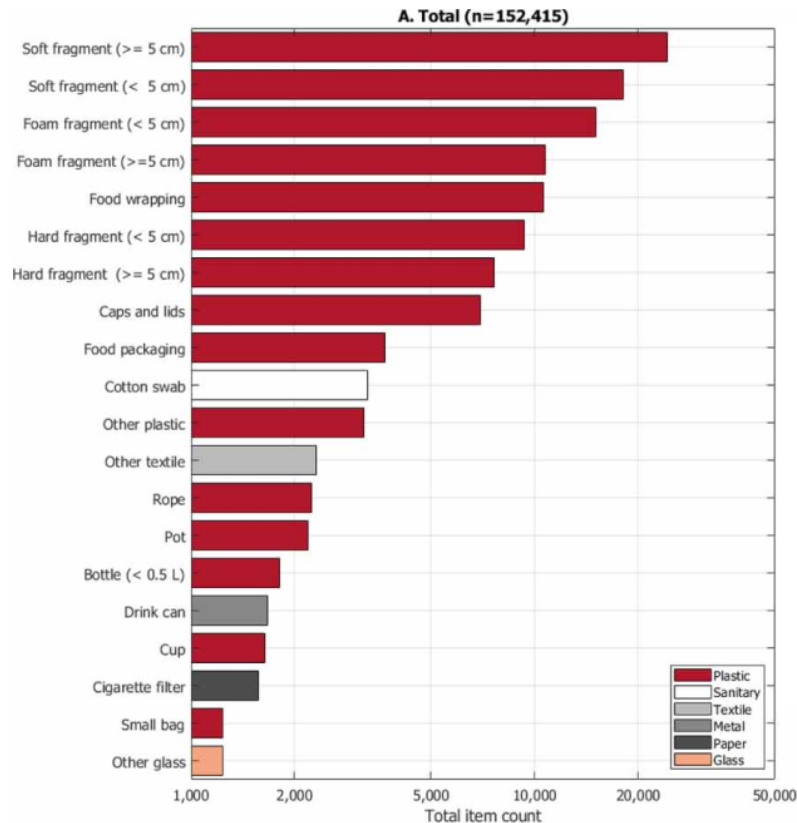

Bron: van Emmerik et al. (2020), Riverbank macrolitter in the Dutch Rhine-Meuse delta 


\section{Project 8}

\section{Trendanalyses zwerfafval}

- Hoe: Analyseren van data verzameld tijden nulmetingen over meerdere jaren en het bepalen van seizoen- en jaartrends

- Wanneer: Projectduur 2 - 3 jaar

- Wie: In-house (RWS)

- Vervolgprojecten na dit project

- Bepalen van mogelijke bronnen zwerfvuil

- Eerste indicatie voor gerichte aanpak

- Referentieprojecten

- RIMMEL project

- van Emmerik et al. (2020), Riverbank macrolitter in the Dutch Rhine-Meuse delta

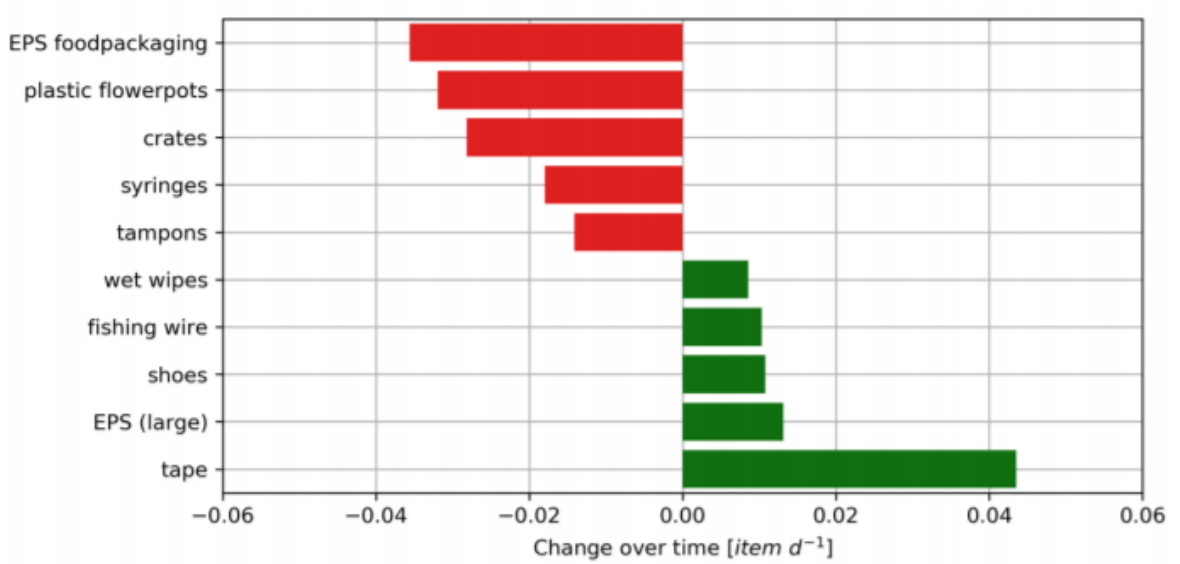

Bron: van Emmerik et al. (2020), Evaluation of River-OSPAR method 


\section{Project 9}

NOS Nieuws Sport Uitzendingen TEEREs:

18. Aantoonbaar effect maatregelen

- Hoe: Monitoren voor en na het invoeren van maatregelen om te bepalen hoe effectief deze zijn. Dit kan pas zodra langetermijnobservaties beschikbaar zijn.

- Wanneer: Projectduur 1 - 3 jaar

- Wie: In-house (RWS) en projectpartners

- Vervolgprojecten na dit project

- Gerichte aanpak van zwerfvuil bronnen

- Referentieprojecten

- Schone rivieren

- RIMMEL project
Vanaf volgend jaar statiegeld op kleine plastic flesjes, later mogelijk ook op blik

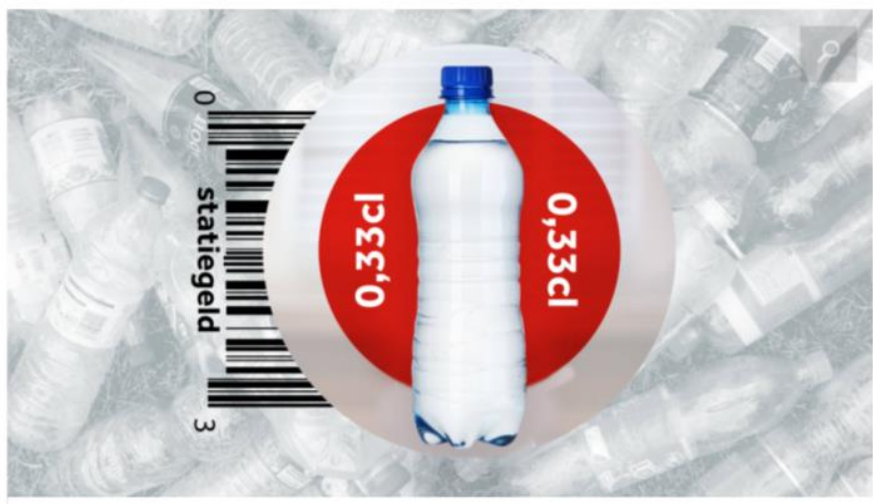

Bron: NOS 


\section{Project 10}

\section{Vaststellen grens- en streefwaarden}

- Hoe: Grens- en streefwaarden opstellen gebaseerd op huidige waarden vastgesteld met nulmetingen en haalbaarheid

- Wanneer: Projectduur 1 jaar

- Wie: In-house (RWS)

- Vervolgprojecten na dit project

- Gerichte aanpak van zwerfvuil bronnen

- Referentieprojecten

- Opstellen van grens- en streefwaarden binnen RWS van andere vervuiling

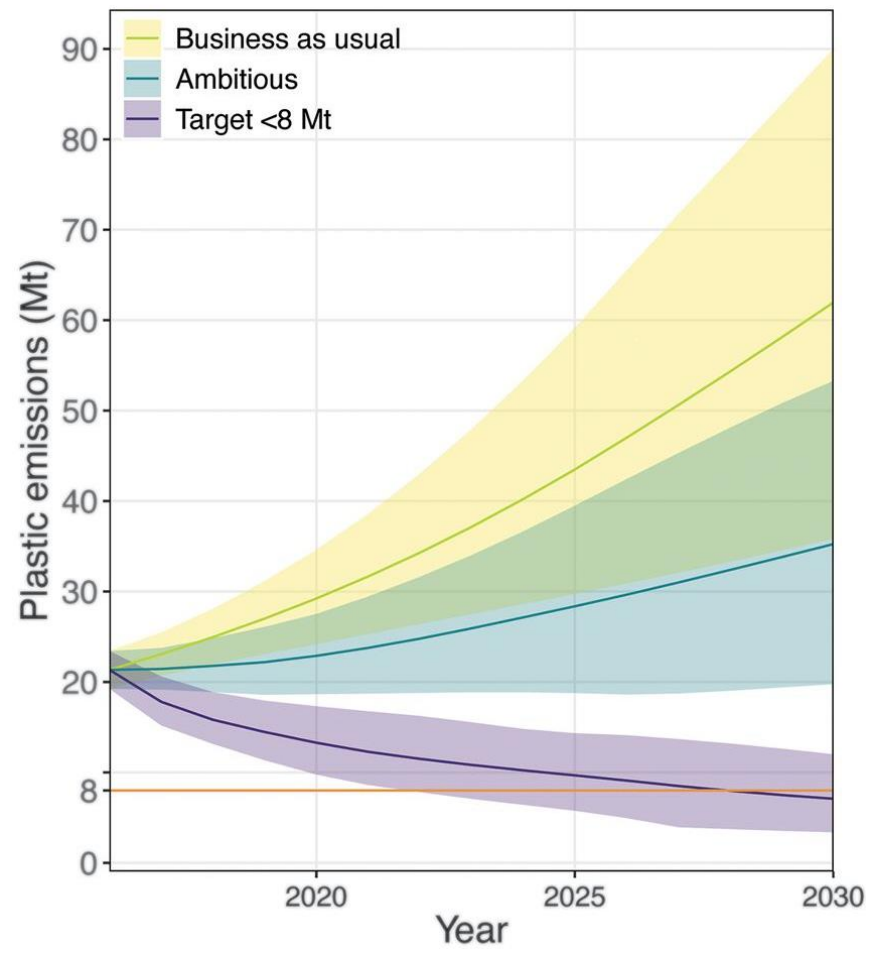

Bron: Borelle et al. (2020) 


\section{Project 11}

\section{Integrale langetermijnmonitoring}

- Hoe: Structureel monitoren van zwerfafval in alle rivier compartimenten, na het ontwikkelen en testen van methodes.

- Wanneer: Projectduur (minimaal) 5 jaar

- Wie: In-house (RWS), meetpartners, eventueel via citizen science

- Vervolgprojecten na dit project

- Kwantificeren van langetermijneffecten van genomen maatregelen

- Bijsturen van genomen maatregelen

- Referentieprojecten

- Langetermijnmonitoring van andere vervuiling binnen RWS

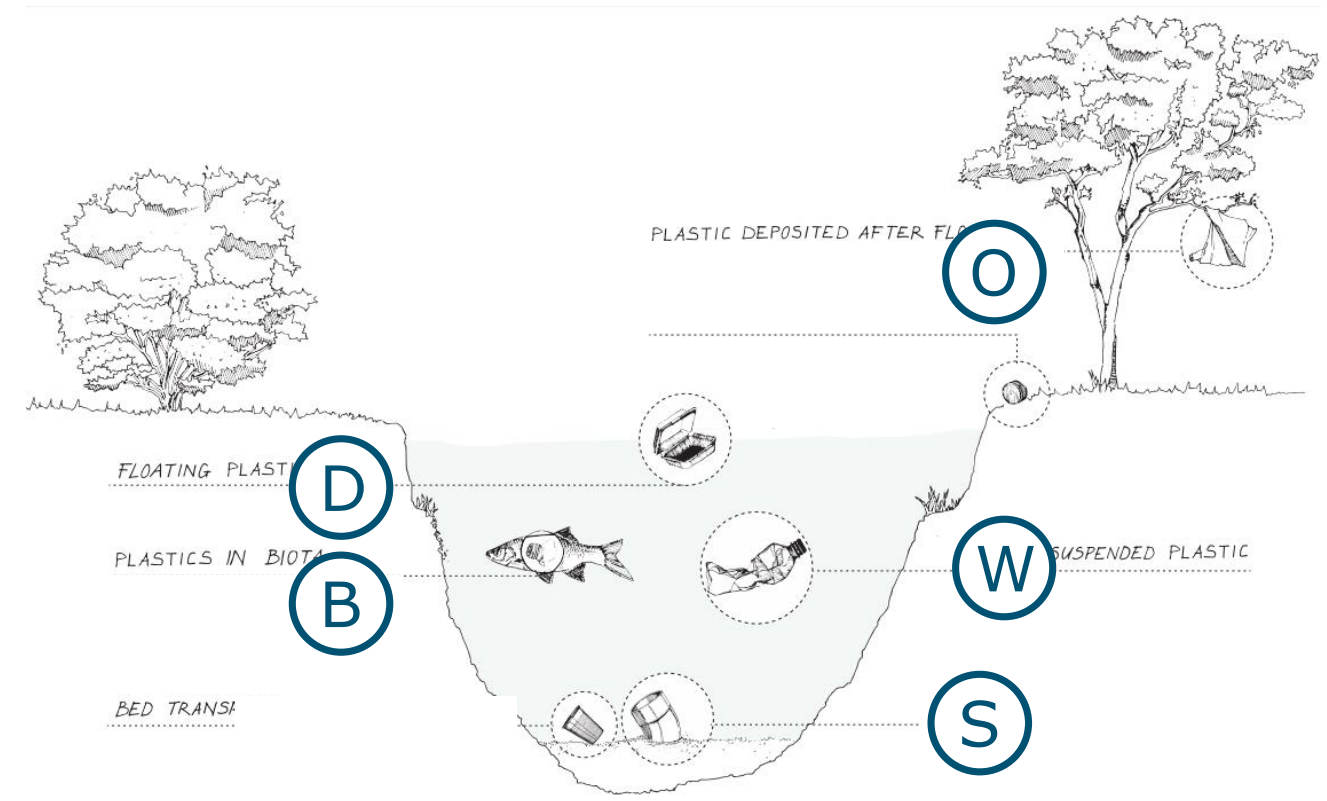

Bron: van Emmerik \& Schwarz (2020) 


\section{Project 12}

\section{Ontwikkelen methode emissie naar zee}

- Hoe: Bepalen van de effecten van het estuarium op het transport van zwerfafval naar zee. Mogelijk blijft zwerfafval in het estuarium hangen.

- Wanneer: Projectduur $1-3$ jaar

- Wie: In-house (RWS), meetpartners

- Vervolgprojecten na dit project

- Kwantificeren van Nederlandse zwerfafval emissies naar de Noordzee

- Referentieprojecten

- Van Emmerik et al. (2020). Manila River Mouths Act as Temporary Sinks for Macroplastic Pollution

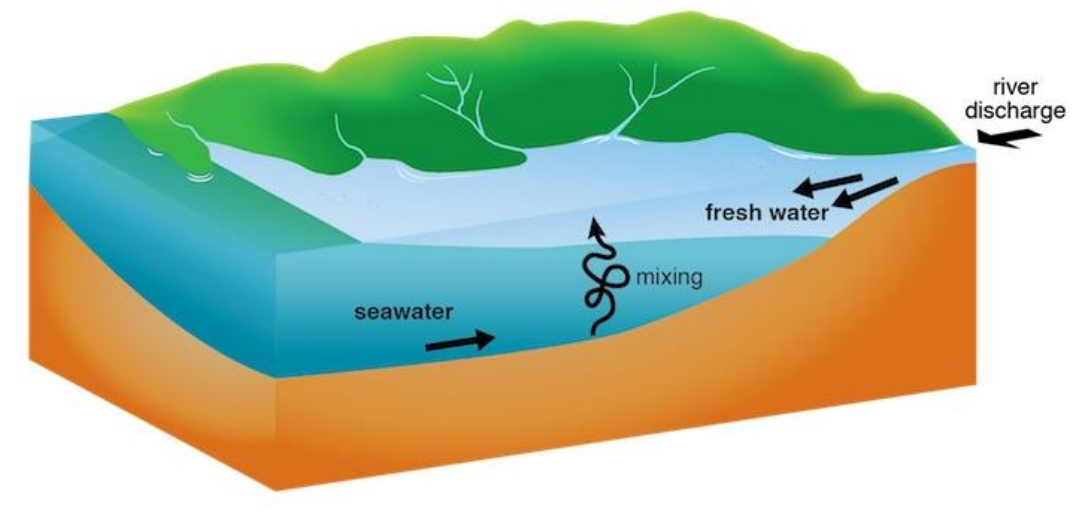

Bron: Restore the Mississippi delta 